ARS Vera Beatriz Siqueira*

ano 15

n. 31

\title{
A floresta geométrica de Paul Claudel: fronteira entre dois mundos.
}

The geometric forest of Paul Claudel: frontier between two worlds.

palavras-chave:

Paul Claudel; 0 homem e seu desejo; floresta tropical; cruzamentos de moderno;

clássico e primitivo

keywords:

Paul Claudel; Man and his desire; tropical forest; crossings of modernism; classicism and primitivism
$\mathrm{O}$ artigo parte da análise do balé $\mathrm{O}$ homem e seu desejo, criado por Paul Claudel (poema plástico), Darius Milhaud (música) e Audrey Parr (cenografia e figurino) quando estavam no Rio de Janeiro entre 1917 e 1918. A ideia básica é pensar essa obra como parte integrante dos diálogos interculturais que fundam a modernidade global do início do século XX, investigando o papel desempenhado pela cultura e pela natureza brasileira no projeto de Claudel de articulação entre vanguarda, classicismo e primitivismo.

This article analyses the ballet Man and his desire, created by Paul Claudel (poème plastique), Darius Milhaud (music) and Audrey Parr (set and costume design), when they were in Rio de Janeiro, in 1917 and 1918. The essential idea is to think this work as part of the cross-culture dialogues that founded the global modernity of the early 20th century, investigating the role of Brazilian culture and nature in Claudel's project of articulation between avant-garde, classicism and primitivism.

* Universidade do Estado do Rio de Janeiro [UERJ]. 
Em 1917, quando era ministro plenipotenciário (embaixador) da França no Rio de Janeiro, tendo por secretário o compositor Darius Milhaud (1892-1974), o poeta Paul Claudel (1868-1955) assistiu a uma das apresentações da turnê sul-americana de Les Ballets Russes ${ }^{1}$, na qual foi encenada a peça L'après-midi d'un faune (A tarde de um fauno), coreografada e dançada por Vaslav Nijinsky (1889-1950) (Fig. 1). Impactado por esse balé, que havia desconcertado o público parisiense em 1912, com suas imagens violentamente eróticas, Claudel entrega-se à escrita de seu "poema plástico" L'homme et son desir (O homem e seu desejo) como base para um balé, aproveitando-se da proximidade com o talento musical de Milhaud e as habilidades artísticas da esposa do diplomata inglês no Rio, Audrey Parr (1892-1940), a quem havia conhecido alguns anos antes em Roma. Inteiramente composta no Brasil, a obra foi coreografada posteriormente por Jean Börlin (1893-1930), de Les Ballets Suédois ${ }^{2}$, estreando em Paris no Teatro de Champs-Élysées em 6 de junho de 1921.

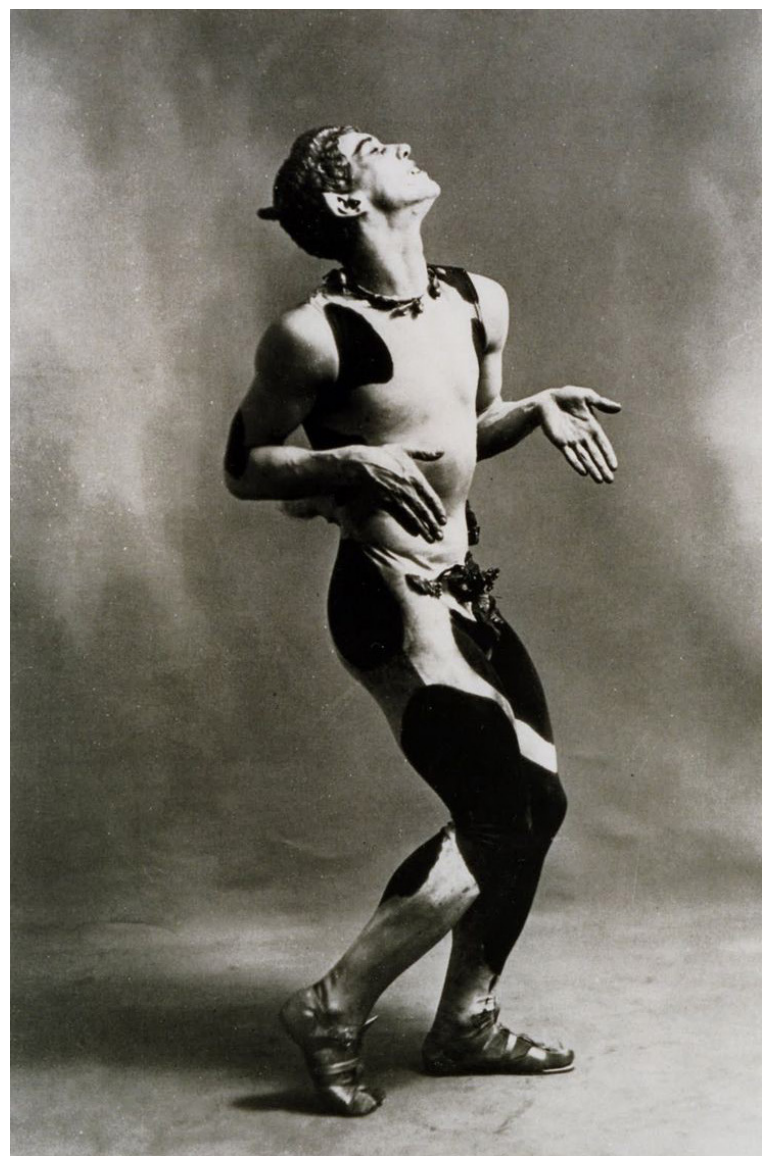

56

Vera Beatriz Siqueira

A floresta geométrica de Paul

Claudel: fronteira entre dois

mundos.

1. Les Ballets Russes era uma companhia de dança clássica, dirigida pelo bailarino e coreógrafo Sergei Diaghilev, que emigrou da Rússia e se instalou em Paris, onde atuou entre 1909 e 1929.

De 1912, ano de estreia de L'aprés-midi d'un faune, a 1921, dedicou-se especialmente às pesquisas modernas no campo do balé. Durante a Primeira Guerra Mundial, devido à impossibilidade de se apresentar nos grandes palcos europeus, Diaghilev se empenhou para conseguir novos espaços, o que levou à segunda turnê sul-americana da companhia, em 1917 (a primeira ocorrera em 1913).

2. Les Ballets Suédois era um grupo predominantemente sueco, estabelecido em Paris entre 1920 e 1925, no contexto do entreguerras europeu. Dedicava-se especialmente a peças que combinavam dança, drama, pintura, poesia, música, circo, acrobacias, filme e pantomima, de modo a propor o que seu diretor, Rolf de Maré, chamava de "síntese da arte moderna". Atuou na Europa e nos Estados Unidos, destacando-se pela força visual de suas peças e pelo interesse pelas culturas populares e não ocidentais.

Fig. 1

Vaslav Nijinsky em L'aprés-midi d'un faune, 1912. (foto Walery). Acervo da Biblioteca-museu da Ópera de Paris, Paris. Fonte: <https://goo.gl/7epEkL>. 
Em realidade, o projeto de Paul Claudel parece ser, desde o início, participar ativa e conscientemente do debate cultural que cerca o L'après-midi d'un faune a partir de sua experiência no mundo natural e cultural brasileiro. A coreografia de Nijinsky, inspirada diretamente na música de Claude Debussy (1862-1918) que, por sua vez, dialoga com o poema homônimo de Stéphane Mallarmé (1842-1898), realiza-se contra um pano de cena que alude a um mundo natural, construído de modo estilizado por áreas de cinza, terra e ocre. Tal cenário serve, igualmente, para compactar o espaço cênico, contribuindo para o desenvolvimento lateral dos movimentos dos bailarinos, já que a ideia original de Nijinsky, Serguei Diaghilev (1872-1929), fundador da companhia Les Ballets Russes, e Léon Bakst (1866-1924), pintor responsável pelos cenários e figurinos, era fazer uma dança inspirada nos vasos gregos vistos no Museu do Louvre, de forma a acentuar o arcaísmo do encontro do fauno com as ninfas descrito no poema. A coreografia aposta em movimentos em linhas paralelas, como se fosse um friso animado. A música é conduzida pela flauta, instrumento do próprio fauno, que, no início, aparece sozinho no palco, se alimentando de cachos de uvas. À medida em que entram as ninfas, outros instrumentos de sopro e corda vão se juntando. A melodia se torna intensa quando se processa o encontro do fauno com os grupos de ninfas. Ao final, novamente sozinho no palco, sob o som de flauta, do violoncelo e da harpa, Nijinsky se curva sobre o lenço deixado por uma das ninfas e simula uma relação sexual e um orgasmo. Com a cabeça jogada para trás, o fauno abre a boca e ri, encerrando-se o balé e a música (Fig. 2).

Fig. 2

Vaslav Nijinsky na cena final de L'aprés-midi d'un faune, 1912. (foto Adolph de Meyer). Fonte: L'aprés-midi d'un faune (catálogo do espetáculo), 1914

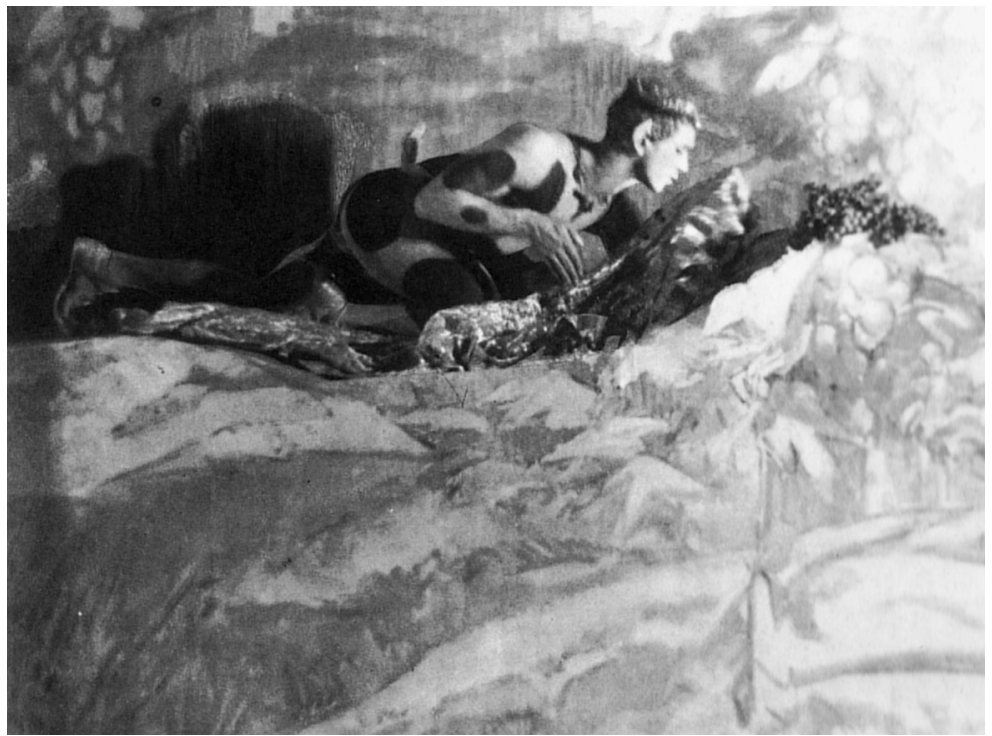


Tudo aí, portanto, diz respeito à tradição clássica e suas releituras na modernidade francesa. O poema de Mallarmé, que tanto demorou a ser publicado, devido a sucessivas recusas pelas revistas e editoras, foi ilustrado por xilogravuras de Édouard Manet (1832-1883) em 1876. Algum tempo depois, inspirou Debussy a criar o seu Prelúdio (1894) e Paul Gauguin (1848-1903) a produzir uma escultura em madeira (1892). No início do século XX, foi Henri Matisse (1869-1954) quem se deixou impregnar pelo clima do poema, dando origem a uma das pinturas-chave da arte moderna ocidental, a tela La joie de vivre (Alegria de viver, 1905-1906), com título alusivo ao romance de Émile Zola de 1883 (1840-1902) e cuja recepção por Pablo Picasso (1881-1973) gerou, por sua vez, outra obra central para a história da arte moderna, a pintura Les demoiselles d'Avignon (As moças de Avignon, 1907). Pouco depois, é a vez de Nijinsky se envolver com o texto de Mallarmé - explicado ao bailarino por Jean Cocteau (1889-1963) -, e com a música de Debussy, criando a impactante coreografia (1912). Todas essas sucessivas interpretações e leituras do poema mostram que se tratava de um problema cultural de grande relevância.

Em todas as recriações visuais da trama, o tema essencialmente clássico do encontro do fauno com as ninfas aparece conectado à modernidade artística e a referências a culturas não-europeias (ou ditas "primitivas"). Na edição luxuosa ilustrada por Manet, o artista inclui um ex-libris que reproduz um nenúfar de um dos volumes do célebre mangá de Katsushika Hokusai (1760-1849) (Fig. 3 e 4). Reverberações da arte japonesa também são perceptíveis na delicada vinheta de cacho de uva que encerra o texto, ou mesmo na conformação dos tufos de plantas nos quais se enredam fauno e ninfas. O contato com esse Oriente gráfico, além do próprio uso da xilogravura, permite a Manet se aproximar do simbolismo de Mallarmé de modo franco, rude e material, atualizando e estendendo a abrangência do tema clássico. O "bibelô primitivo" de Gauguin, oferecido ao poeta (que o dispõe em sua casa ao lado do Minotauro de Rodin), é uma escultura semelhante a um totem, feita em baixo-relevo e madeira cilíndrica, na qual se identifica, de um lado, uma figura feminina de tipo maori, com longos cabelos, e de outro uma figura masculina com patas de bode (Fig. 5). A mitologia clássica encontra-se com a da Polinésia: o fauno se converte em Fatou, deus da Terra, e a ninfa vira a deusa da Lua, Hina ${ }^{3}$.
58

Vera Beatriz Siqueira

A floresta geométrica de Paul

Claudel: fronteira entre dois mundos.

3. Esse mesmo tema foi tratado de modo direto pelo pintor, ainda em 1893, na tela Hina te Fatou, exposta no fim do ano na galeria Durand-Ruel e adquirida por Edgar Degas (1834-1917). Hoje pertence ao acervo do Museu de Arte Moderna de Nova lorque. 
ARS

ano 15

n. 31

Fig. 3

Ilustração de Édouard Manet para o livro de Stéphane

Mallarmé, L'aprés-midi

d'um faune, Paris: Alphonse

Derenne, 1876. Exemplar número 60 , vendido pela

Sotheby's em 2014. Fonte:

<https://goo.gl/88JkHb>.

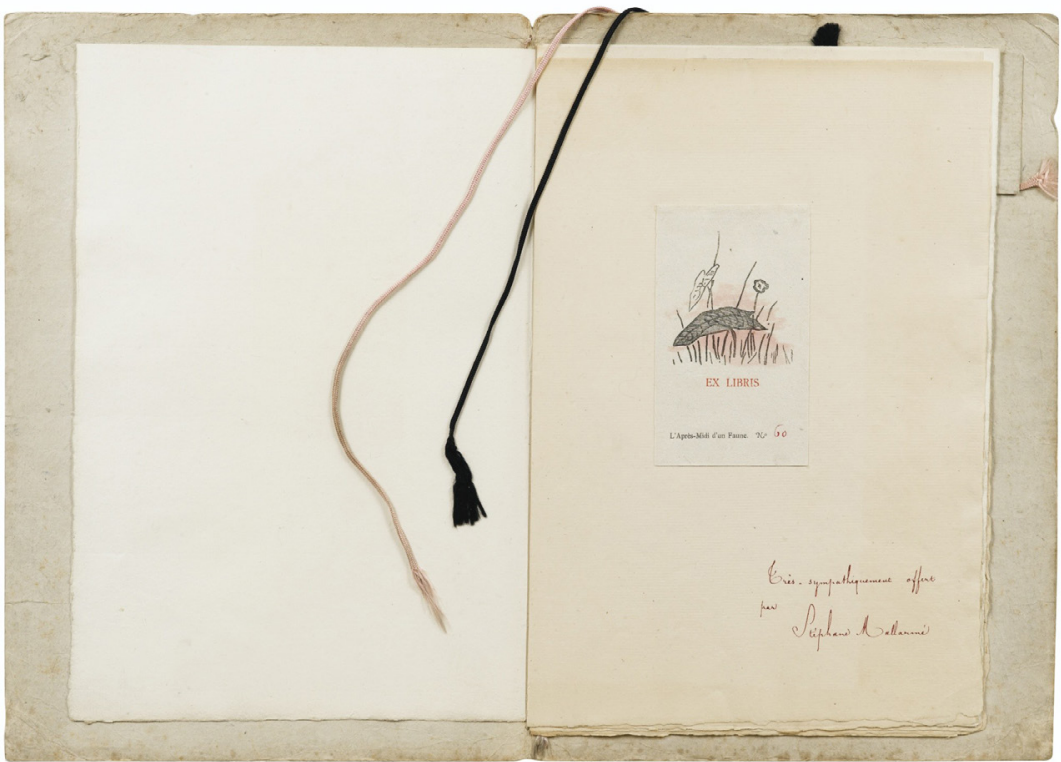

Fig. 4

Hokusai, Mangá, volume 5 :

Plantas, 1814. Fonte: <https:// goo.gl/xgjsFJ>.

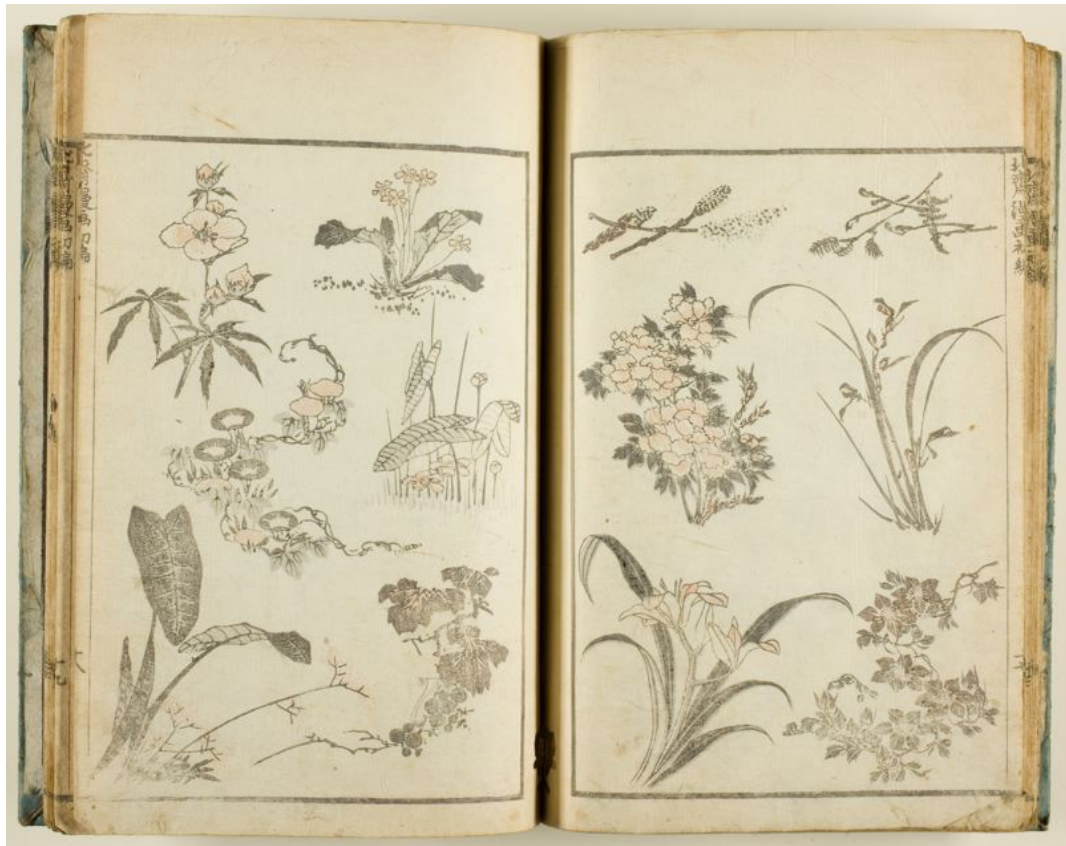




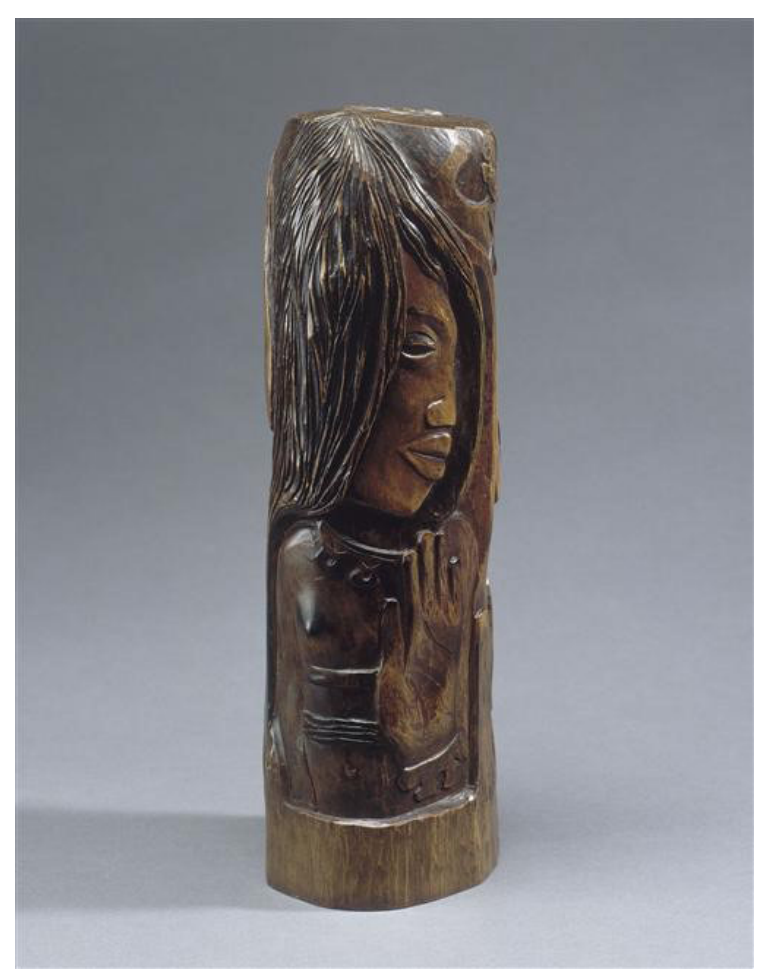

Por fim, a tela de Matisse associa, de modo direto, a Arcádia com a sexualidade e a natureza. As cores fortes do pintor, vinculado ao fauvismo, seus arabescos e os grupos de figuras que se unificam poeticamente falam de uma nova concepção de lirismo e beleza, possíveis apenas no trabalho artístico. Como no poema de Mallarmé, cujo fauno descreve sua tarde na indecisão de ser um sonho ou uma vivência real, tendo apenas um lenço perdido para estabelecer esse elo misterioso entre realidade e imaginação, a tela de Matisse parece nos dizer que toda aquela "alegria de viver" só está disponível, no mundo moderno, na arte e na poesia, capaz de construir um classicismo que é universal por incluir o seu outro. E será certamente Picasso, desafiado por essa obra de Matisse, quem nos mostrará com clareza a relevância do vínculo matissiano com o primitivo, ao qual busca dar novo rumo na relação que estabelece entre suas meninas de Avignon e as máscaras africanas.

Claudel procura participar desse debate cultural sobre as relações entre clássico, moderno e primitivo, apropriando-se de sua familiaridade com a natureza e a sociedade brasileira. Ele e seu secretário Darius Milhaud chegam ao Rio de Janeiro às vésperas do carnaval carioca, após 18 dias de travessia de navio. O músico, em sua autobiografia, descreve a chegada:

\section{Vera Beatriz Siqueira}

A floresta geométrica de Paul

Claudel: fronteira entre dois mundos.

Fig. 5

Paul Gauguin, Laprès-midi d'un faune, c. 1892, escultura em madeira. Acervo do Museu Stéphane Mallarmé, Vulaines-sur-Seine. Fonte: <https:// goo.gl/7FsWHX> 
4. MILHAUD, Darius apud

THOMPSON, Daniela. As crônicas bovinas, parte 30 :

Milhaud, seus libretistas diplomatas e a influência do Brasil. Musica Brasiliensis, [S.l.], 17 out. 2003. Disponível em: <https://goo.gl/wkU2XG>. Acesso em: 28 nov. 2017.

5. Ibidem.

Fig. 6

Paul Claudel, Darius Milhaud e Henri Hoppenot Itambém funcionário da Legação Francesa no Rio de Janeirol no Brasil, c. 1917-18. Ifoto publicada no artigo de Daniella Thompson, As crônicas bovinas, parte 30 . Fonte: <https://goo.gl/wkU2XG>

Nós chegamos ao Rio no dia $1^{\circ}$ de fevereiro de 1917 , em um dia quente e brilhante como se fosse pleno verão. Claudel arrumou alojamento para mim com ele na legação francesa; magnificamente situada na Rua Paissandu, uma rua margeada por palmeiras imperiais da ilha da Réunion às vezes com mais de sessenta metros de altura e coroadas com copas pendentes de sete metros. ${ }^{4}$

O deslumbramento com a natureza tropical continua:

O Rio possuía um forte charme. É difícil descrever a baía adorável, circundada por montanhas com formas fantásticas cobertas por uma leve tintura de florestas ou coroadas por solitários picos rochosos marrom-avermelhados, algumas vezes cobertas por fileiras de palmeiras que se projetavam como penas de avestruz na luminosidade almiscarada dos trópicos contra um céu amortalhado por nuvem cinza-perolada. ${ }^{5}$

Esse pequeno trecho aponta para o tom da relação do poeta e do músico com a paisagem brasileira: uma sorte de encanto com seu caráter indescritível, suas formas fantásticas e inusitadas aos olhos europeus, que tornam essencial a sua vivência. Milhaud se compraz em narrar seus passeios pela cidade, quando aproveitava para provar refrescos de frutas no Centro, admirar o colorido da Igreja da Glória, encantar-se com a arquitetura divertida das casas na orla de Copacabana ou simplesmente entregar-se à paisagem do Rio, caminhando pelos arredores da Tijuca, vendo as luzes cintilantes delinearem a Baía ou deitando-se na praia deserta de Niterói à noite, para ler sob o luar (Fig. 6).

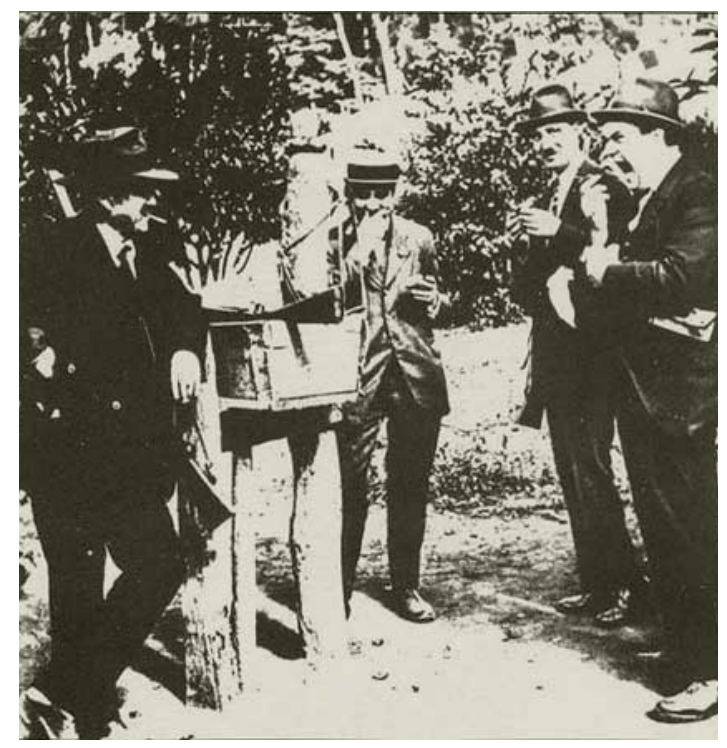


Mas o que interessa acima de tudo a Milhaud é a música popular brasileira, pela qual se deixa influenciar de modo decisivo ${ }^{6} . \mathrm{Na}$ cidade em que aportaram, segundo relato do compositor, tocava-se insistentemente o samba "Pelo Telefone"7, assim como tangos, maxixes, cateretês e outros sambas, executados por bandas militares, orquestras de cinemas, pianos dos palacetes, pianos mecânicos e fonógrafos das casas do Flamengo, violões seresteiros das ruas, vozes solitárias de negros e bêbados. Em artigo inédito, escrito no Mills College em 1944, intitulado "Influence of Latin-American music in my work" ("Influência da música latino-americana em meu trabalho"), Milhaud relembra os anos que passou no Brasil como "gloriosos". Agradece a oportunidade que teve de estudar o folclore brasileiro, o ritmo dos tangos, sambas e maxixes ou a melancolia dos fados lusitanos. A associação entre esses ritmos e a natureza é imediata: "Eu podia assistir aos bailes de Carnaval dos negros e podia assimilar gradualmente as curvas desses ritmos que são tão flexíveis quanto as folhas enormes das palmeiras-imperiais imperais" ${ }^{\text {. }}$

Por sua vez, Claudel, apelidado de "Cacique" por Audrey Parr, evocando outra sorte de homem "primitivo", entende o contato com o Brasil - como havia vivido antes na China - como um choque sensorial e sensual. Claudel fala de uma certa pungência que impregna a alma e não a abandona mesmo anos depois de daqui sair. Também contempla, diariamente, as palmeiras imensas da Rua Paissandu, com seus troncos gigantes terminados por "tufos prodigiosos" de folhas de grande efeito sob a luz da lua9. Admira a vegetação que qualifica de "violenta e crua", criada por um Deus cansado das "harmonias da Natureza, dos planos muito chatos, das montanhas muito redondas, sem falar nas pequenas encostas moderadas que são a glória de departamentos franceses”. Esse Deus extravagante pede a um de seus empreiteiros que fabrique algo brilhante para "apimentar" o continente sul-americano. O demiurgo sai então a pesquisar, "nos limites de sua imaginação", "todos os tipos de materiais excêntricos e inutilizáveis". Quando tudo começa a tomar forma sob o sol dos Trópicos, o empreiteiro é tomado de um acesso de pudor e desânimo que o faz lançar tudo, sem voltar-se para ver o resultado, no mar da Baía de Guanabara, que acaba por se converter, nas palavras de Claudel, em uma espécie de "Luna Park geográfico"10.

Como nas descrições de Milhaud, a paisagem brasileira assume tonalidades fantásticas e fabulosas. Indescritíveis, em realidade, a não ser pelo recurso poético a uma história que costura as pontas do mais absoluto ao mais comum, do arcaico ao contemporâneo, do
62

Vera Beatriz Siqueira

A floresta geométrica de Paul

Claudel: fronteira entre dois mundos.

6. Milhaud compôs diversas peças inspiradas na música brasileira, com destaque para "O boi no telhado" - uma colagem vanguardista de sambas, maxixes e tangos para o balé homônimo apresentado em 1920 em Paris - e para a suíte de danças "Saudades do Brasil", que evoca lugares do Rio e amigos com que aí conviveu. Sobre a influência da música brasileira em sua obra, cf. LAGO, Manuel (org.). 0 boi no telhado: Darius Milhaud e a música brasileira no modernismo francês. São

Paulo: Instituto Moreira Salles, 2013.

7. "Pelo telefone" é considerado, pela maioria dos autores, como o primeiro samba a ser gravado no Brasil. Foi criado em 1916 no quintal da casa da Tia Ciata, na Praça Onze, no Rio. A composição foi registrada em novembro de 1916 no nome de Donga que, mais tarde, acrescentou Mauro de Almeida como parceiro. Há entretanto controvérsias sobre sua autoria, pois segundo alguns teria sido uma criação coletiva, com participação de nomes como Pixinguinha, Sinhô, entre outros. Houve também, na época, divergências na própria qualificação da música, que foi chamada de "tango brasileiro".

8. THOMPSON, Op. cit.

9. Carta de Paul Claudel a Francis Jammes, 25 set. 1917. In: RIVIĖRE, Jacques (org.). Paul Claudel, Gabriel Frizeau, Francis Jammes: correspondance 1897-1938. Paris: Gallimard, 1952, p. 294. 
ARS imaginativo ao real. E é justamente a percepção dessa qualidade in-

ano 15

ก. 31

10. CLAUDEL, Paul. Au Brésil (1936). In:

Oeuvres en prose. Paris: Gallimard, 1965, p. 1095. A referência ao Luna Park evoca a imagem do parque aberto em 1903 em Coney Island, Nova lorque, local que reunia praia, casas de banho, bares e restaurantes, brinquedos e jogos, além de hotéis, constituindo um parque de diversões em si mesmo. decifrável da natureza tropical que parece ter levado Claudel a querer redimensionar e radicalizar o debate entre clássico, moderno e primitivo. O seu balé dirige-se muito claramente a isso. É escrito no Brasil para ser encenado na França; para ser representado diante de um determinado público acostumado às fantasias simbolistas e expressionistas, capaz de elaborar a profundidade da floresta brasileira, tão diversa, para Claudel, das descrições empíricas e fotográficas dos livros de viagem.

Desde os primeiros relatos de viagem ao Novo Mundo, manifestou-se um problema de tradução: como fazer com que o europeu, com os limites de seu quadro intelectual e de sua imaginação, conseguisse entender as cenas mais improváveis, os costumes mais distantes, os homens mais diversos? Na realidade, o problema é mesmo anterior: como descrever essa realidade inédita, que nunca fora nomeada ou analisada pelos estudiosos clássicos? Escritores e desenhistas lidam com esse dilema de tradução, que enfrentam com as armas que possuem: a visão de mundo ocidental, as convenções imagéticas classicizantes. E assim constroem imagens que se situam entre a realidade (ou verdade) e a percepção (ou imaginação). Para Claudel, também será o encontro desses dois mundos o problema a ser enfrentado: a floresta tropical na qual se ambienta o drama do balé é a selva real, concreta, íntima e sensivelmente experimentada por ele, com suas cores, barulhos e insetos, mas também aquela que não se deixa decifrar, que recusa toda forma de compreensão intelectiva e permanece misteriosa, escura, vertical e profunda. Lugar privilegiado, portanto, para dispor o seu homem primitivo, básico, sem nacionalidade, no contato com o que possui de mais interior: o desejo sexual.

\section{A floresta geométrica}

Em sua estada no Rio, Claudel dedica-se a admirar e conhecer a natureza tropical. Faz longas excursões nos arredores de Teresópolis, no Saco de São Francisco, nas montanhas da Tijuca, no Bico do Papagaio, ou mesmo na floresta virgem do Mato Grosso, de carro, trem, canoa, a pé ou a cavalo (Fig. 7). Mas também se encarrega de estimular intercâmbios culturais com a França, acolhendo artistas dramáticos e líricos europeus em turnê, como a dançarina e atriz Régina Badet (1876-1949), o ator André Brulé (1879-1953), o tenor Enrico Caruso (1873-1921), a bailarina Anna Pavlova (1881-1931), o pianista Arthur Rubinstein (1887-1982) ou a trupe dos Ballets Russes. Essa 
companhia não apenas encenava peças clássicas de seu repertório, como reproduzia, na sala de baile da Legação de França no Rio algumas das coreografias mais discutidas em Paris, como aconteceu com trechos do balé Parade de Jean Cocteau (1889-1963), com coreografia de Léonide Massine (1896-1979), música de Erik Satie (1866-1925) e cenografia de Picasso. Claudel, que havia se posicionado há tempos contra a "perfeição estúpida" do balé clássico, apreciava as novidades coreográficas, com especial destaque para o L'après-midi d'un faune de Nijinsky, de quem não gostava até então, mas cuja avaliação é completamente modificada após assistir a este balé, passando a elogiar a "cumplicidade elástica" de todo seu aparelho muscular e nervoso, o "corpo que não é de um tronco ou uma estátua, mas o órgão inteiro de pulsação e movimento" ${ }^{11}$.

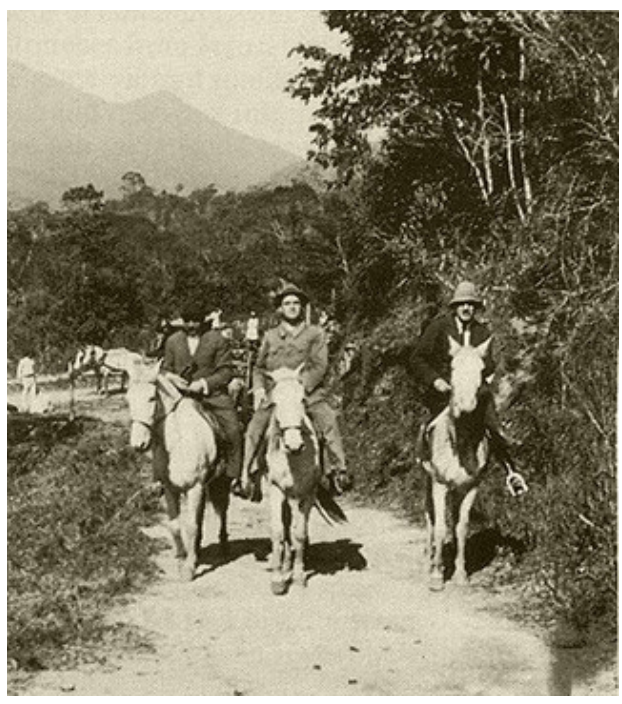

Encantado com a dança e com o bailarino, Claudel convida Nijinsky para longas caminhadas na Floresta da Tijuca. Queria convencê-lo a coreografar e encenar seu balé brasileiro, L'homme et son désir, mas também desejava fazê-lo entender a atmosfera da floresta tropical. Claudel admirava especialmente a vasta uniformidade da Mata Atlântica, a impossibilidade de se identificar elementos particulares, o que tornava o todo um elemento único, uma massa vegetal inextricável na qual se experimentava a profundidade e o mistério da experiência da imersão. Nem Claudel nem Milhaud sabiam, na ocasião, que a carreira de Nijinsky viria a terminar justamente após a turnê latino-americana, devido às primeiras manifestações da esquizofrenia que o levou para longe dos palcos.

\section{Vera Beatriz Siqueira}

A floresta geométrica de Paul Claudel: fronteira entre dois mundos.

11. NIJINSKY, Vaslav apud FLEURY, Raphaèle. Le Petit Théâtre de Petrópolis: un monde-joujou pour laboratoire artistique: Paul Claudel, Audrey Parr et Darius Milhaud, Brésil 19171918. In: COLÓQUIO LABEX BRASIL-FRANÇA, 1., 2016, São Paulo. Anais... São Paulo: Laboratoire d'Excellence des Arts et Médiations Humaines; Museu de Arte Contemporânea, 2016, p. 211. Disponível em: <https://goo. $\mathrm{gl} / 4 Q \mathrm{QJWW}>$. Acesso em: 28 nov. 2017.

Fig. 7

Paul Claudel, Darius Milhaud e Henri Hoppenot a cavalo no Brasil, c. 1917-18. (foto publicada originalmente no Livro de Paul Collaer, Darius Milhaud, 1947. Fonte: <https:// goo.gl/wkU2XG>. 

continuou a ser desenvolvido no contato com a floresta brasileira. Uma primeira série de experimentações plásticas para dar forma aos planos de Claudel e Milhaud acontece na casa de Audrey Parr, em Petrópolis, em um pequeno teatro portátil que se colocava sobre a mesa, à moda do teatro de papel ou toy theater, difundido na Europa, a partir da Inglaterra, no século XIX. Vendidos na forma de pranchas coloridas ou para colorir, esses teatros de dimensões reduzidas traziam personagens e cenários emblemáticos da tradição teatral europeia, destinando-se a brincadeiras de crianças e adultos cultos. Sobre a experiência específica na casa de Parr, Milhaud recorda: "poucas obras nos foram tão divertidas de construir" ${ }^{2}$. O jogo produzido por esse teatro joujou, foi a base da criação da estrutura cênica e coreográfica do balé. É ainda Milhaud quem descreve:

Acima as Horas, abaixo a Lua e as Nuvens, no meio o Drama, o Homem e a Floresta, drama da noite, do sonho, da lembrança e do amor, e enfim abaixo de tudo o reflexo da Lua e das Nuvens. Nós recortávamos os personagens de 15 centímetros em papéis coloridos e foi assim que criamos todo o nosso balé. ${ }^{13}$

13. MILHAUD apud WASSERMAN, Michel. De la Serra des Orgues au Théâtre des Champs-Élysées. Bulletin de la Société Paul Claudel, Paris, n. 201, p. 21-29, 2011, p. 22. Disponível em: <https:// goo.gl/uWMXBk>. Acesso em: 28 nov. 2017.

14. CLAUDEL, Paul; PARR, Audrey. L'homme et son désir, poème plastique, 1918. In: GETTY RESEARCH INSTITUTE. Getty Research Institute Archive. Los Angeles, 1985. Texto manuscrito acompanhado de colagens e desenhos, montados sobre cartão, exemplar n. 10 uma edição manuscrita e numerada com colagens de Parr ${ }^{14}$ (Fig. 8). Trata-se de um álbum dobrado à japonesa, ou leporello-fold, de 32 centímetros, com sete painéis duplos. Alguns exemplares recebem a anotação "Petrópolis, 1917", outros têm a inscrição "Rio de Janeiro, 1918". O lado da frente contém colagens com o texto escrito à mão por Claudel, emolduradas por desenhos que mostram bailarinos e ornamentações de Audrey Parr em tinta azul. O verso é formado por colagens de silhuetas de músicos e seus instrumentos, com detalhes em dourado contra o fundo azul da parte superior e recortes geométricos de notas musicais dispostos sobre uma pauta que ocupa cerca de dois terços da página. Esse álbum nos mostra como a proposta do balé era, em realidade, fundada na conciliação das tradições clássicas e modernas europeias com uma certa concepção necessariamente vaga e ampla de primitivo, que associava exótico e popular. 


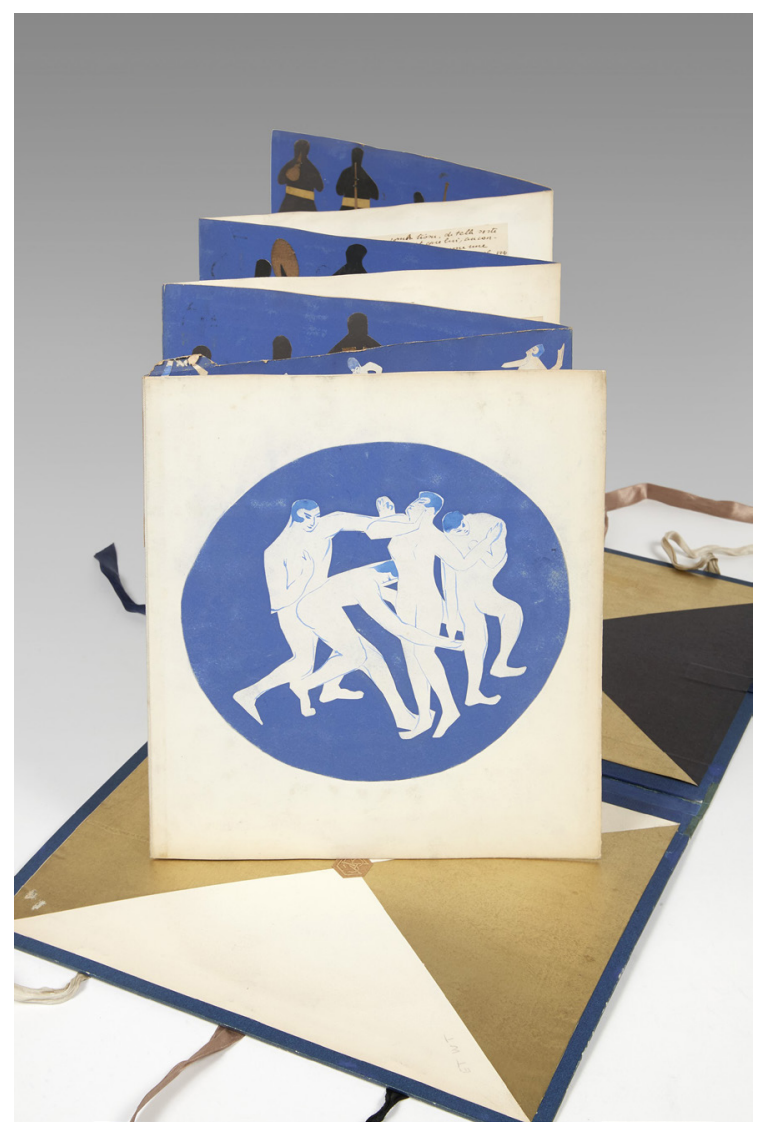

66

\section{Vera Beatriz Siqueira}

A floresta geométrica de Paul

Claudel: fronteira entre dois mundos.

Fig. 8

Paul Claudel e Audrey

Parr, L'homme et son désir, Petrópolis, 1917. Exemplar número 35 , vendido pela Sotheby's e Bibliorare. Fonte: <https://goo.gl/Jkj52h>.

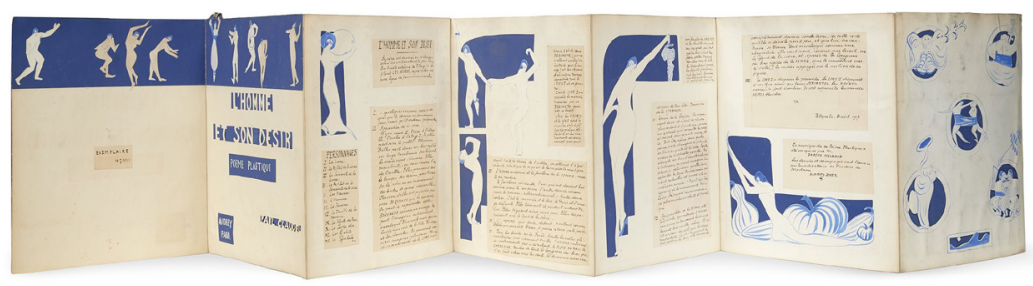

\section{Fig. 9}

Painéis da frente do livro Paul Claudel e Audrey Parr, L'homme et son désir. Petrópolis, 1917.

Fig. 10

Painéis do verso do livro Paul Claudel e Audrey Parr, L'homme et son désir, Petrópolis, 1917. 

o primitivo à Grécia das figuras de bailarinos, cujo linearismo remete, simultaneamente, ao Art Nouveau e ao Oriente (Fig. 9). Primitivo também pode ser o aspecto algo medieval das silhuetas hieráticas e dos dourados dos músicos no verso (Fig. 10), que, por sua vez possuem um quê - ou para usar uma expressão bem francesa, um je ne sais quoi - de África, Europa Oriental e Oriente Médio que o ritmo decorativo das notas musicais geométricas parece reforçar. Primitivo pode ser ainda o próprio aspecto lúdico e pueril de todo o arranjo e a manufatura mambembe da publicação que, de outro lado, se conecta à cultura popular moderna. E ainda podemos falar de primitivo a partir do azul que costura tudo, remetendo aos chamados "pintores primitivos italianos", como Giotto, aos azulejos portugueses que os intelectuais admiram no Brasil, à porcelana chinesa de gosto ocidental da Companhia das Índias. Mas que não deixa de se ligar à experiência de todos eles da própria natureza tropical, referindo-se tanto aos azuis de céu e mar da Baía de Guanabara, como à luminosidade da floresta, especialmente no momento em que é ambientado o enredo do balé, quando a floresta começa a escurecer, deixando-se povoar por ruídos, movimentos e reflexos de luar.

O tema básico do "poema plástico" de Claudel é por ele mesmo descrito como uma alegoria do Homem primitivo, que se entrega ao êxtase, ao desejo e à morte no contato com a força feminina e com a natureza. Antes de sua versão brasileira, o escritor já havia explorado enredo semelhante no conto La lanterne aux deux pivoines (A lanterna com duas peônias), adaptação de uma antiga história chinesa, publicada originalmente no livro Jiandeng Xinhua (Novos contos sob a luz da lâmpada) de Qu You (1341-1427), mas que Claudel havia lido no livro Le folklore chinois moderne (O folclore chinês moderno, 1909) do padre jesuíta francês Léon Wieger (1856-1933). Escrito em Praga em 1910, o conto narra o amor do estudante Kio, que se deixa seduzir por uma bela jovem, com quem se encontra regularmente após a hora fatal da meia-noite. Um vizinho curioso flagra o estudante se entretendo amorosamente com um monstro, com cabeça de morta, hediondamente vestida. Advertido, o moço consegue se afastar por um tempo do espectro - que enxergava, com sua visão embaçada pela paixão, como uma jovem bela e radiante -,

15. MALICET, Michel. Lecture psycanalythique de l'oeuvre de Paul Claudel: les structures dramatiques ou les fantasmes du fils. Paris: Presses Universitaires Franche-Comté, 1979, v. 1, p. 89. mas acaba por ceder novamente ao desejo e morre em seus braços.

Ao fazer uma análise psicanalítica da obra de Claudel, Michel Malicet destaca a associação constante entre a morte e as personagens femininas, que se apresentam como "silhuetas inquietantes ou terríveis", responsáveis pelo clima de penumbra e pesadelo de muitas de suas obras $^{15}$. Também Yehuda Moraly, em seu estudo de L'homme et son désir, 
afirma que a mulher morta do balé é o reflexo de todas as outras mulheres ausentes desejadas por Claudel, transformando a peça em um autobiográfico elogio à loucura e ao mundo para além da razão ${ }^{16}$. Ainda que não entremos na seara da interpretação psicanalítica, esse pequeno conto de inspiração oriental possui alguns elementos nitidamente semelhantes ao balé escrito no Rio, entre os quais o mais importante, o fantasma da mulher morta que vem tentar o homem durante a noite. A conexão China, França, Brasil serve para reforçar o sentido primordial e universal do Homem de Paul Claudel, associando o primitivo a questões antropológicas básicas, como a sexualidade, o desejo, a castração, a morte.

$\mathrm{O}$ primitivo reaparece ainda em seu estudado medievalismo simbolista $^{17}$, que o leva a conceber o balé de forma semelhante ao Livro de Horas medieval: O homem e seu desejo é composto por oito seções, cada uma delas com uma imagem estática dominante e suas figuras personificando estados psíquicos e espirituais - o Homem, a Mulher, as Horas, a Lua. O balé de cerca de 30 minutos desenvolve-se a partir do tema básico do encontro do homem adormecido com o fantasma da mulher morta. A cena inicial evoca a atmosfera da floresta noturna, para onde o fantasma feminino conduz o Homem, esse personagem arquetípico, que tanto pode ser um homem de carne e osso quanto o homem dentro do sonho. As quatro partes que se seguem - "Aparição da Lua", "O Homem adormecido e o fantasma da mulher morta", "O Homem que dorme em pé, oscilando como uma corrente de água e como se não tivesse peso" e "Todas as coisas da floresta que vêm ver o Homem adormecido" falam justamente das tentações que esse homem deve enfrentar em seu sono. A sexta e a sétima partes - "Dança da paixão" e "Reaparição da Mulher que conduz o Homem lentamente revelando a si mesma diante dele" - apresentam a entrega do homem ao desejo, figurado pela dança exaltada da mulher. Ao final, o oitavo movimento, como seu próprio título descreve, enfatiza a relação com o Livro de Horas Medieval e sua função ordenadora do tempo: "A Lua 1 desaparece primeiro, a Lua 2 desaparece por sua vez. As Horas negras passam. Podemos ver a entrada das primeiras Horas brancas. O tempo e a floresta permanecem". A passagem regular do tempo oferece o consolo da eternidade, relativizando os dramas particulares do homem.

Mas ainda precisamos falar de outro aspecto desse primitivo amplo e global que interessava a Claudel: a sua atualidade, em conexão com a modernidade. As experiências do teatro de papel e dessa publicação artesanal possuíam antes de tudo, como o próprio escritor admite, a importância de ter trazido para os artistas envolvidos em sua realização o contato com uma forma de criação artística moderna, imediata e
68

Vera Beatriz Siqueira

A floresta geométrica de Paul

Claudel: fronteira entre dois mundos.

16. MORALY, Yehuda. La fôret, la folie, la nuit: un ballet de Paul Claudel. Revue de la Société d'histoire du théâtre, Paris, n. 1, p. 5-36; p. 94-95, 1997.

17. Segundo análise de Mary Fleischer, Paul Claudel, Jean Börlin and the Ballets Suédois. Cf. FLEICHER, Mary. Embodied texts: symbolist playwright-dancer collaborations. Amsterdam; New York: Rodopi, 2007. 
independente, na qual têm destaque a materialidade e a espacialização como formas de escritura. Ao descrever o balé, Claudel afirma:

18. CLAUDEL, Paul. L'Homme et son désir: le gaulois, 4/06/1921. In Théâtre

2. Paris: Gallimard, 2011 p. 1143

19. Sobre a estruturação cênica em patamares na obra de Claudel, cf. BERETTA, Alain. Une caractéristique scénique claudélienne: la scène à étages. Bulletin de la Société

Paul Claudel, Paris, n. 203, p. 40-50, 2011. Disponível em: <https://goo.gl/UEkxKS>. Acesso em: 28 nov. 2017.

Fig. 11

Projeto de Audrey Parr para L'homme et son désir, 1921. Publicado em Les Ballets Suédois dans l'art contemporain. Paris: Éditions du Trianon, 1931. Fonte: <https://goo.gl/uWMXBk>

\begin{abstract}
Não tentamos reproduzir com exatidão fotográfica a inextricável desordem da floresta. Simplesmente a jogamos como um carpete, violeta, verde, azul, ao redor do negro central, nos quatro planos de nossa cena. Esta cena é vertical, perpendicular, dada como uma pintura ou um livro que se lê. Se quisermos, é também como uma página de música, onde cada ação está inscrita sobre uma pauta diferente. ${ }^{18}$
\end{abstract}

Ao observarmos o projeto de Parr para esse cenário (Fig. 11), as pontas de moderno e primitivo voltam a se encontrar. A verticalidade da floresta, da qual Claudel sempre falava após suas incursões pela Mata Atlântica, se converte em radicalidade plástica moderna, definindo um espaço que rompe com as regras tradicionais de composição e recusa a perspectiva única. A profundidade é dada pelo escalonamento vertical dos planos em direção ao fundo do palco. O tapete verde que forra os diferentes níveis, sobre o qual se fixam formas geométricas coloridas, contribui para transformar a floresta em uma experiência abstrata, correlato moderno da sua inextricabilidade. $\mathrm{O}$ balé ocorre em cada um dos quatro níveis simultaneamente, com os grupos de bailarinos agindo em ritmo e movimento próprios, independentes, portando ou manipulando formas de gota ou círculos recortados em papelão. Esse espaço em níveis, ainda que se ligue a certa tradição cênica ${ }^{19}$, era desafiador para a dança por exigir uma drástica limitação dos movimentos dos bailarinos, que precisavam se deslocar ao longo da linha horizontal de cada plataforma, como em uma imagem pictórica bidimensional.

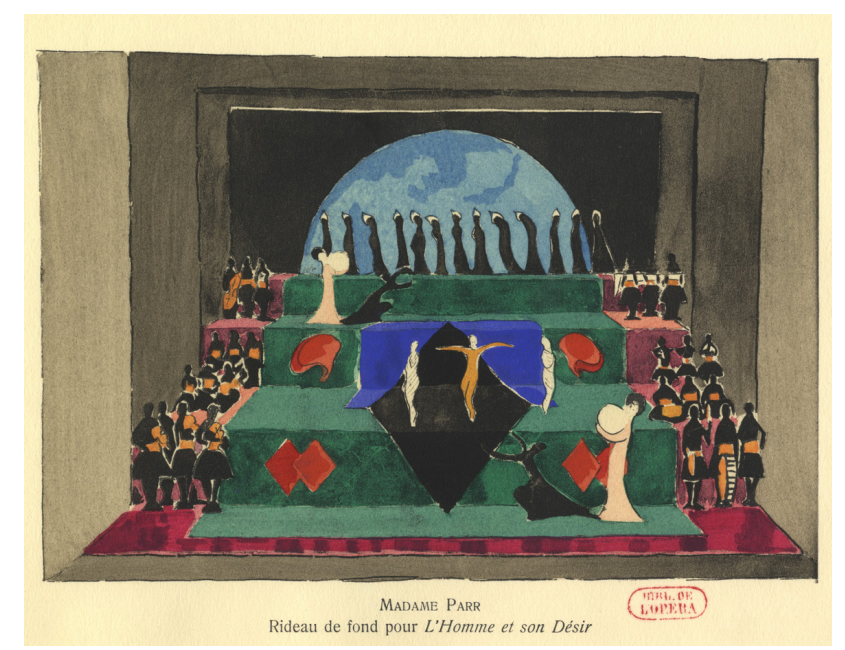


No nível superior ficam as Horas, mulheres que se movem muito lentamente, quase imperceptivelmente, de um lado a outro. Sua procissão extremamente vagarosa começa antes da música. Tratava-se, como Claudel gostava de apontar, do constante fluxo temporal da natureza, representado em termos cênicos. O fundo desse patamar é pintado de preto, sobre o qual se representa a metade superior do globo terrestre, numa clara citação do célebre Livro de Horas do Duque de Berry. No patamar abaixo e no nível do palco, movem-se as Luas e seus servos-Nuvens, respectivamente no céu e refletidos na água. Esses casais de bailarinos também apresentam movimentos mínimos, vagarosos, limitados, deslocando-se lateralmente pela linha das plataformas. Em uma carta de 1926, Claudel produz um curioso elogio às marionetes que, ao contrário dos atores vivos, têm seus gestos derivados apenas da ação: "[a marionete] se torna viva na performance, como uma sombra que trazemos para a vida dizendo-lhe tudo o que fazer e gradualmente... torna-se uma presença" ${ }^{20}$. Para Claudel, os bonecos representariam a pureza do movimento, despedido de toda memória que possa afetá-lo. Suas Horas e Luas, portanto, movem-se como construções semi-humanas, através do uso da potência dinâmica do corpo humano para configurar e mobilizar elementos não corpóreos.

Apenas o Homem está livre dessas restrições de movimento, embora assuma outra forma de lentidão e passividade, pois está dormindo, seus pés mal tocam o chão e é, em realidade, manipulado pelo fantasma da Mulher. Muitas críticas foram feitas aos limites técnicos do bailarino Börlin (Fig. 12), mas aquilo que os críticos chamavam de gestualidade excessiva, semelhança física com uma escultura clássica ou drama exagerado parecem não contradizer, ou mesmo realçam, o artificialismo que Claudel almejava. Os limites de sua técnica e capacidade expressiva contribuíam para a formação desse balé que se aproxima de uma obra de arte cinética, movendo formas estáticas e discutindo a figura do homem como um visitante estranho no eterno fluxo da natureza e do tempo.

A fornecer o ritmo para esses movimentos estava a música de Darius Milhaud, hoje celebrada como a peça clássica ocidental que mais deu destaque à percussão, confiando importantes seções do balé exclusivamente ao conjunto de instrumentos percussivos, valendo-se em outras partes da percussão como voz orquestral dominante ou produzindo um rufar de tambores que funciona como base das melodias. Em termos gerais, a música é animada, revelando múltiplas influências de ritmos brasileiros populares. Como um correlato da disposição espacial do cenário, Milhaud opta por um conjunto estereofônico, mundos.

20. TROTT, Alex. Dynamism and design in the Ballets Suédois's L'Homme et son désir. In: DAVIES, Rhys; TOWNSEND, Christopher; TROTT, Alex (eds.). Across the Great Divide: modernism's intermedialities, from futurism to fluxus. Cambridge, UK: Cambridge Scholars, 2014, p. 55. 
ARS assim descrito por ele mesmo: "no terceiro andar, de um lado: um quarteto vocal, do outro: o oboé, o trompete, a harpa, o contrabaixo.

n. 31 No segundo andar de cada lado, instrumentos de percussão. Em um lado do primeiro andar: a flauta de Pã, a flauta, o clarinete baixo e do outro lado: um quarteto de cordas. Eu desejava conservar uma inteira

21. MILHAUD, Darius. Notes sans musique. Paris: Julliard,

1949, p. 95. independência, melódica, tonal e rítmica, desses diversos grupos"21. A orquestra acabou por se apresentar no fosso. Porém, alguns instrumentos foram manipulados por bailarinos, e os músicos nos patamares foram substituídos por silhuetas recortadas, semelhantes às da publicação de 1918 (Fig. 13).

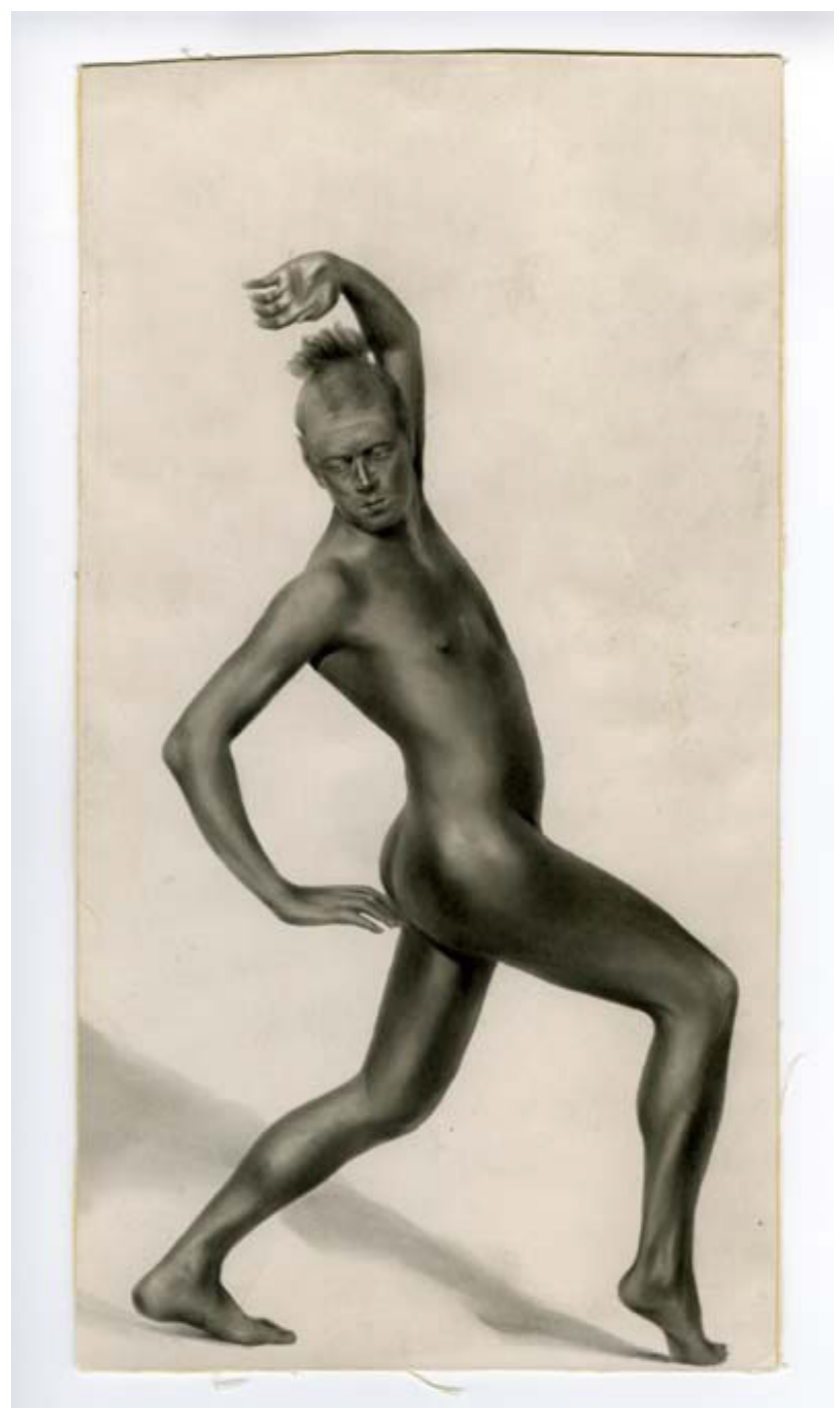

Jean Börlin em L'homme et son désir, 1921. (foto Isabey). Acervo do Museu da Dança, Estocolmo. Fonte: <https:// goo.gl/uWMXBk>. 


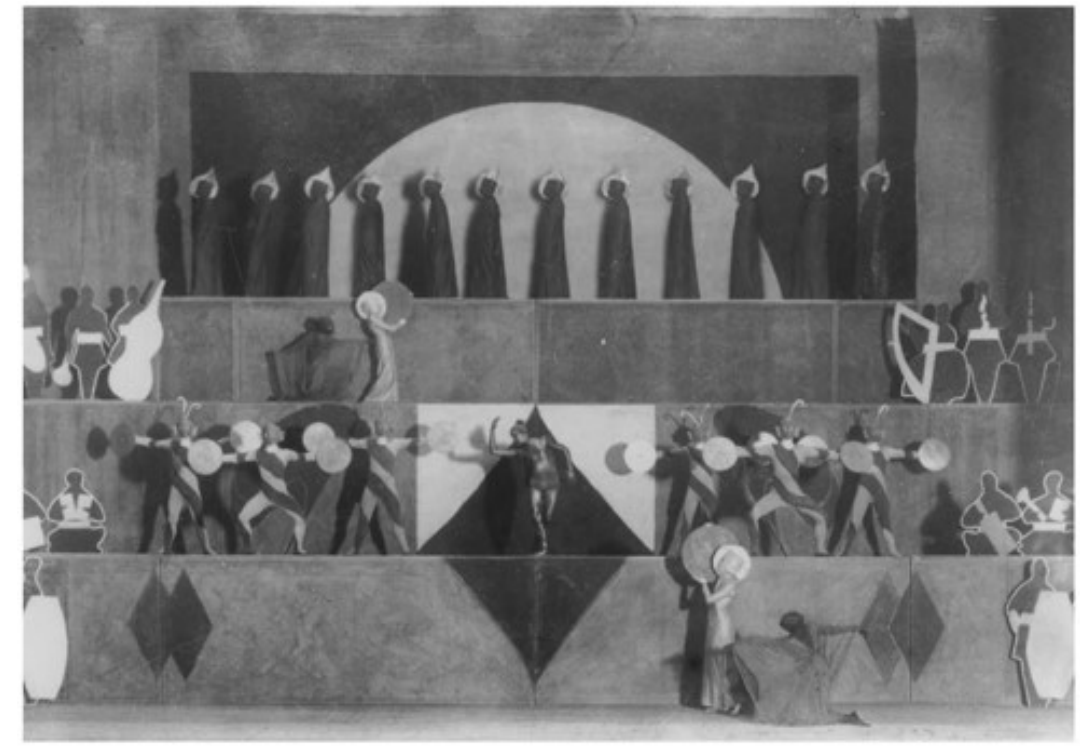

Sobre essa experiência de Milhaud, o jornalista Lawrence Gilman escreveu, em 1923, quando da apresentação do balé em Nova Iorque:

Com uma orquestra que aparentemente inclui todo tipo de instrumentos de percussão e que produz ruídos conhecidos pelo homem, de furadeiras pneumáticas a apitos da polícia, Milhaud faz coisas incríveis. Enquanto se escuta, o imenso e rude terror da noite tropical se mistura a uma sensualidade por vezes surgida como ferocidade animal e por vezes como refinada sutileza, que deixa a orquestra e nos persegue. Combinado aos instrumentos, vale-se do efeito de vozes sem palavras por trás das cenas, o que é frequentemente de uma beleza original e assustadora; e o clímax frenético e bárbaro é algo difícil de ser esquecido. ${ }^{22}$

Complementando essa radicalidade cênica e musical, vinha o figurino criado por Audrey Parr, ecoando ou antecedendo várias experiências cenográficas modernas ${ }^{23}$. As Horas do patamar superior aparecem envelopadas em grandes véus negros que lhes cobrem as cabeças adornadas por uma auréola dourada em forma de gota. Ao final da peça, algumas delas aparecem vestidas de branco, sugerindo o amanhecer. As duas Luas totalmente vestidas de branco também possuem uma auréola redonda e escura, e carregam consigo uma espécie de disco branco preso aos braços, representando o astro lunar. Os seus servos, que dançam ajoelhados, são vestidos com múltiplas capas pretas, para criar com seu movimento o efeito de nuvem que Claudel imaginara. Os bailarinos ao redor do Homem são, ao mesmo tempo, criaturas da floresta
72

\section{Vera Beatriz Siqueira}

A floresta geométrica de Paul

Claudel: fronteira entre dois mundos.

Fig. 13

Montagem de L'homme et son désir no Thêatre des Champs-Élysées, 1921. (foto Isabey). Publicada em Encyclopédie du Théâtre contemporaine 2. Fonte: <https://goo.gl/ uyFGwy>.

22. GILMAN, Lawrence apud FLEISCHER, Mary, Op. cit., p. 297.

23. A cenografia e os figurinos de Audrey Parr são considerados, na história dos Ballets Suédois, uma das experiências mais modernas e radicais. A presença dos instrumentistas-bailarinos (sinos, pratos e flauta de Pã), as silhuetas recortadas de músicos que ocuparam o lugar originalmente pensado para a orquestra e o tapete geométrico e colorido que representava a floresta foram elementos bastante polêmicos, espantando mesmo aqueles que já estavam acostumados à participação de artistas vanguardistas nos espetáculos da companhia. Sobre isso, cf. DE GROOTE, Pascale. Ballets Suédois. Ghent: University of Ghent Press, 2002. 
e instrumentos da orquestra. Apenas para dar alguns exemplos, os que tocam os pratos portam máscaras de insetos e antenas; quando manipulam os instrumentos presos aos braços parecem abrir e fechar suas asas (Fig. 14). O flautista de Pã tem o corpo e o rosto completamente tampados e é recoberto de raízes que lhe conferem aspecto vegetal. A harpista veste-se com uma malha que lhe reveste o corpo e o rosto, tendo nas costas e na parte de trás da cabeça uma sorte de escamas que lhe faz lembrar um animal anfíbio.

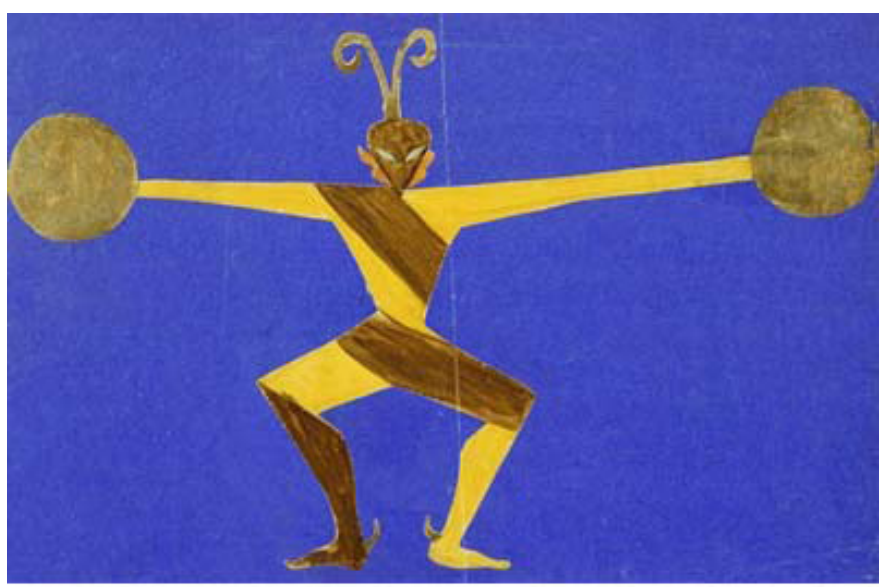

Fig. 14

Audrey Parr, figurinos para $L a$ Cymbale (0 Prato) e La Femme (A mulher), 1921, colagem e desenho sobre papel. Acervo do Museu da Dança, Estocolmo. Fonte: <https:// goo.gl/uWMXBk>.

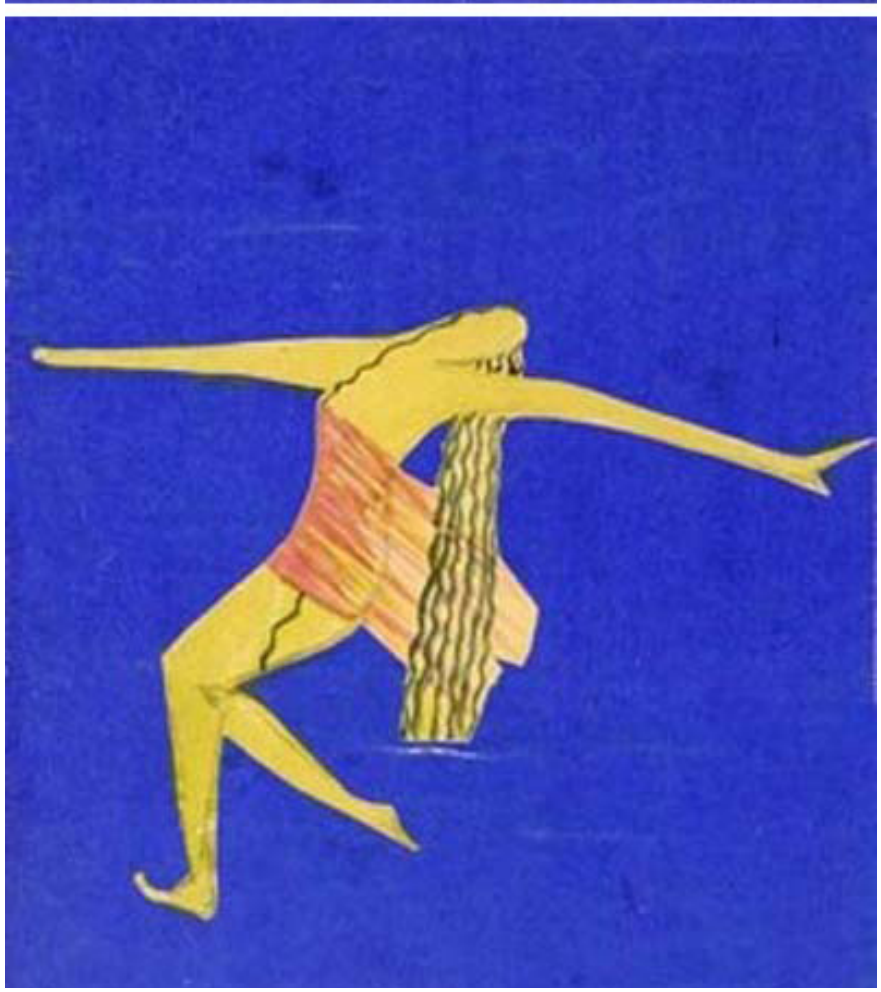


O Homem e a Mulher estão nus, embora seja apenas uma nudez cênica, escondida por malhas, pela pintura dourada e oleosa do personagem masculino e pelo longo manto que envolve a bailarina. Ao final do balé, a Mulher se despe e cobre o Homem com o seu véu, invertendo os papéis. Quando chegam as Horas brancas, quando cessa o transe e retorna à realidade, o Homem mal saído do sono não pode ver a Mulher e só lhe resta sentir a sua ausência. Os dois saem juntos do palco, afastados pelo rígido braço da Mulher despida. Mas nesse afastamento não há propriamente amargura ou tragédia. Ao contrário, como já dissemos, a marcha regular das Horas e da Lua tem o poder de relativizar o drama, colocando o desejo desesperado no rol das impossibilidades. A dança frenética é redentora na medida que dá lugar ao amanhecer. $\mathrm{O}$ mundo continua. $\mathrm{O}$ que já vinha sendo afirmado desde a cena inicial da procissão das Horas, que, segundo consta no libreto artesanal, deve apenas indicar "que o drama não começa, mas que continua qualquer coisa”.

Não foi à toa, portanto, que L'homme et son désir foi qualificado por vários estudiosos da dança como antibalé. Como destacou Yehuda Moraly,

não se trata de balé, mas de uma obra de arte total, assinada pelo dramaturgo, pelo músico e pela cenógrafa. Uma música no limite da cacofonia, um homem nu, uma mulher nua e uma coreografia que cita gestos cotidianos, cujo ritmo é modificado por Claudel ou repetido até formar uma dança. ${ }^{24}$

O que, evidentemente, trouxe uma série de polêmicas nos diferentes lugares em que o espetáculo foi montado. Às observações críticas sobre o fraco desempenho de Börlin se juntavam a incompreensão do "obscuro libreto de M. Claudel”, a recusa da música ruidosa de Milhaud e o espanto com o próprio cenário e sua pretensão de reproduzir a ambiência da floresta tropical. Um dos críticos chega a se perguntar como "a desordem tropical poderia ser geométrica" ${ }^{25}$. A nudez do bailarino também recebe boa parte dos comentários negativos, por vezes com tons moralizadores. Mesmo críticos que se alinhavam às novas propostas no campo da dança clássica não deixavam de se espantar com o antibalé de Claudel. André Levinson - jornalista de origem russa que se tornou crítico e historiador da dança em Paris - anota a prevalência dos elementos plásticos em detrimento da dança.

Em Nova Iorque, o entusiasmo de Gilman com a radicalidade da música de Milhaud foi compensado pela crítica jornalística que acusava
74

Vera Beatriz Siqueira

A floresta geométrica de Paul

Claudel: fronteira entre dois mundos.

24. MORALY, Yehuda. Claudel metteur en scène: la frontière entre les deux mondes. Paris: Presses Universitaires Franche-Comté, 1998, p. 56.

25. apud WASSERMAN, Op. cit., p. 28. 
a trupe dos Ballets Suédois de ostentação e Eiffel towerism, como se vê

26. DUDLEY, Bide apud FLEISCHER, Mary, Op. cit. p. 299. no comentário sarcástico de Bide Dudley:

O Homem e seu desejo (...) era tão sutil, mesmo em sua explicação impressa, que nós, pobres incultos, não podemos sequer tentar explicá-lo. Podemos dizer apenas que M. Börlin, como o Homem, estava suficientemente nu para exibir seu belo físico enquanto Mlle. Strandin, após um período de exercícios rítmicos, exibiu uma forma física a ser elogiada por qualquer crítica da Broadway. Uma grande quantidade de imaginação é requerida para seguir essa peça. No entanto, nós acreditamos que (...) alguém possa, eventualmente, aprender a gostar dela, mesmo essa pessoa sendo um produto do Meio-Oeste. ${ }^{26}$

\section{Tom, vezo e tempero}

É certo que nessas críticas há muito da recusa conservadora em relação às novidades. Mas é preciso notar que os comentários negativos nos ajudam a perceber um elemento central dessa criação coletiva comandada pelo cacique Claudel. Há algo de produtivamente exagerado e caricato em $O$ homem e seu desejo, que trata o espectador seja como um parceiro cúmplice, seja como um adversário a conquistar. Tudo nos é apresentado de modo voluntariamente estereotipado, convencional. A nudez, o branco da lua, o escuro da nuvem, o verde da floresta, a passagem das horas, a geometria das formas, o reflexo da lua na água, o escalonamento vertical da terra ao espaço - tudo enfim se mostra como uma imagem convencional, na fronteira da caricatura. Aí parecem residir o limite e a relevância da floresta geométrica de Claudel, deliberadamente caricata de seu próprio pitoresco.

É curioso ver o poeta francês, homem essencialmente culto e viajado, escrever à sua irmã:

Os brasileiros são exatamente conforme o que você imagina. Como sempre eu acho as pessoas exatamente iguais à ideia delas feita por aqueles que nunca viajaram. Por exemplo, chinês é um homem que tem um chapéu com sinos e ainda mantém sempre o dedo indicador no ar. Nada mais exato. ${ }^{27}$

27. Carta de Paul Claudel a E. Sainte-Marie Perrin, 20 mar. 1917. In: FLEURY, Op. cit., p. 242-243. perados efeitos de provocação ou piada, desvio ou nostalgia, empatia ou insulto, Claudel se aproxima de um discurso popular e ingênuo, em oposição ao intelectualismo frio das manifestações culturais eruditas. 
Quando escreve sobre lugares que aqui visitou, compara a Baía de Guanabara com o universo dos parques de diversões (o Luna Park geográfico), as casas pintadas em penhasco na Bahia com um cenário de teatro de marionetes Guignol, a "bizarra floresta de araucária" às decorações das fanfarras e às apresentações populares do mágico Rothomago $^{28}$. Na verdade, essas comparações da realidade brasileira com o universo mágico e fabuloso mostram que o que Claudel, Milhaud e Parr, esses três europeus ligados ao mundo das artes, parecem ter levado do Rio de Janeiro em sua bagagem foi um conjunto de imagens indescritíveis ou indecifráveis. Como as elegantes palmas ondulantes da rua Paissandu - a um só tempo símbolos da natureza tropical e da elite, nas palavras de José Wisnik ${ }^{29}$. Ou ainda a verticalidade e a luminosidade noturna e violácea da floresta tropical - esse ambiente violentamente expressivo, incapaz de ser articulado pela razão. Ou mesmo a sociedade brasileira com a qual conviveram, formada, segundo Claudel, por homens ambivalentes que podiam ser tão cavalheirescos, fiéis e generosos quanto brutais, vingativos e perigosos.

Entre a tradição literária, artística e musical europeia a que pertenciam os criadores de L'homme et son désir e o mundo que encontram no Brasil há um hiato difícil de ser transposto ou mesmo compreendido. Como o próprio hiato que Milhaud surpreende no jeito de tocar de Ernesto Nazareth, o "pequeno nada" rítmico, a "imperceptível pausa", a "tomada de fôlego não estudada" na qual reside todo o balanço da música popular. Ao compositor francês cabe constatar e estudar esses pequenos nadas, mesmo sabendo que jamais conseguirá se apropriar deles. Até em suas composições mais decisivamente influenciadas pela música brasileira, revela-se antes de mais nada a sua filiação à tradição escrita da música europeia e à forma sinfônica, em tudo opostas a essa dimensão indescritível da tradição popular, que exige não uma escola, mas uma predisposição cultural e física, um contato demorado e persistente. Claudel refere-se a esse elemento indescritível como "um certo tom, um vezo, um tempero"30 de Brasil, do qual sua alma jamais se livrará.

Talvez a pós-história de L'homme et son désir nos ajude a compreender melhor os impasses e limites dos diálogos culturais nele contidos. Após assistir à estreia do balé no Théâtre des Champs Elysées, Paul Claudel retorna ao posto diplomático no Japão, para o qual havia sido nomeado em janeiro (Fig. 15). Lá, disposto, como disse em seu diário, a reabrir o "grande livro do Oriente", dedicava-se a ver performances de nô, kabuki e bunraku. Claudel visitou diversos templos em Kyoto e Nara. Apreciou os jardins, as estátuas budistas (embora desprezasse o Budismo como religião) e as porcelanas da cerimônia do chá. Manteve
76

Vera Beatriz Siqueira

A floresta geométrica de Paul

Claudel: fronteira entre dois mundos.

28. CLAUDEL, 1965, p. 10951099.

29. WISNIK, José. 0 boi no telhado. 0 Globo, Rio de Janeiro, 8 fev. 2013. Disponível eml: <https://goo.gl/SSBgyV >.

Acesso em: 28 nov. 2017.

30. "Qualquer um pode dizer o que bem entender do Brasil, mas não tem como negar que se trata de um desses países pungentes, que impregnam a alma e a deixam com um certo tom, um vezo, um tempero de que ela nunca mais conseguirá se ver livre". apud WISNIK, Op. cit. 
contato estreito com intelectuais, pintores e profissionais do teatro japonês. No ano seguinte, foi contatado pelo professor Yamanouchi (18941973), seu tradutor e amigo, para adaptar o balé para a cena japonesa. A ideia era que o espetáculo fosse encenado pelo conhecido ator Fukusuke Nakamura (1900-1933), da companhia teatral Hagoromo$K_{a i}{ }^{31}$, com música de Kosaku Yamada (1886-1965). Claudel recusou a proposta, alegando que a peça havia sido composta para europeus e que não teria bom efeito nos palcos japoneses. Mas prometeu reescrever uma readaptação do balé, específica para o Japão.

Fig. 15

Paul Claudel no Japão, 1921. (foto sem autoria). Fonte: $<$ https://goo.gl/9A6HjE>.

31. A companhia Hagoromo-Kai (Sociedade do Robe de Plumal foi criada em 1922 por

Fukusuke Nakamura, com o objetivo de explorar novos métodos de performance, no quadro da crise do kabuki, após o declínio da cultura samurai no final do século XIX. Uma das vias de inovação era o rompimento com os limites do repertório tradicional e a criação de novas peças, baseadas muitas vezes em material ocidental, o que levou à encenação do texto de Paul Claudel. É interessante perceber como o encontro do poeta francês com o teatro japonês nos fala da revisão moderna da tradição clássica na Europa e no Japão.

32. 0 Teatro Imperial, ou Teatro Jardim Imperial, foi fundado em 1911, em Marunouchi, distrito comercial de Tóquio, com arquitetura em estilo ocidental. Ficou conhecido por dedicar-se especialmente ao kabuki, abrindo-se, porém, a peças de inspiração europeia.

33. Carta de Claudel a Elizabeth de Sainte-Marie Perrin, 8 mar. 1923. apud MORALY, Op. cit., p. 59.

34. Ibidem, Loc. cit.

A nova obra, intitulada La femme et son ombre (A mulher e sua sombra), apresentada no Teatro Imperial de Tóquio ${ }^{32}$ em março de 1923, buscava adaptar o balé anterior ao repertório temático, aos personagens e às técnicas de movimento do teatro japonês. Em carta à sua cunhada, Claudel fala que se trata de "uma espécie de balé, ou sobretudo de nô", no qual as mímicas, a dança e a música seriam "puramente japonesas" ${ }^{\prime 3}$, e apresenta o projeto:

Terá cinco orquestras, uma para cada personagem. A música que escutei é exitosa. Retomei a ideia da Lua e seu reflexo, aperfeiçoando-a. A Lua, precedida de seus servos em grandes chapéus negros por cima e prateados por dentro, passará no nível superior por trás de galhos de pinheiro e no inferior por trás de folhas de lótus. Para o reflexo, no lugar da imagem exatamente repetida, haverá três bailarinos, cada um com um espelho na mão. ${ }^{34}$

Há um longo debate entre os estudiosos de artes cênicas, que certamente foge ao escopo deste texto, sobre se este balé seria uma peça 
nô ou um kabuki. Menos relevante do que distinguir as duas formas teatrais seria concluir que Claudel não percebia propriamente conflito entre ambas. Ao contrário, no texto em que escreve para a reapresentação do balé em 1948 na França, o poeta relaciona as tradições cênicas japonesas: "O drama nacional, o nô, tem por tema quase único a conversação comentada por um coro de um morto com um vivo. O kabuki, que é a forma mais moderna, apenas desenha sobre esse repertório"35.

Nota-se, portanto, uma comunhão temática e poética entre o teatro nô e o balé de Claudel na representação do encontro entre sonho e realidade. $\mathrm{O}$ escritor retoma as figuras centrais do teatro nô: o shite (fantasma), encarnado na sombra, e o waki (aquele que sonha), geralmente encarnado por um monge ou viajante, que na peça de Claudel ganha um sentido mais ativo com o guerreiro. $\mathrm{O}$ nô também possui uma estrutura precisa e fixa - a dupla aparição do shite; a dança da cura e a libertação de uma alma -, da qual Claudel se acerca de modo menos rígido. Escrito para o Teatro Imperial, o texto parece se aproximar mais do que se chama kabuki de dança, composto como um espetáculo de variedades, apoiado especialmente no desempenho do ator-bailarino, revelando uma leitura mais livre das tradições cênicas japonesas (Fig. 16). Como sugere o estudioso da obra de Claudel no Japão, Isao Yamamoto, La femme et son ombre é uma obra bastarda: kabuki na forma, nô no fundo.

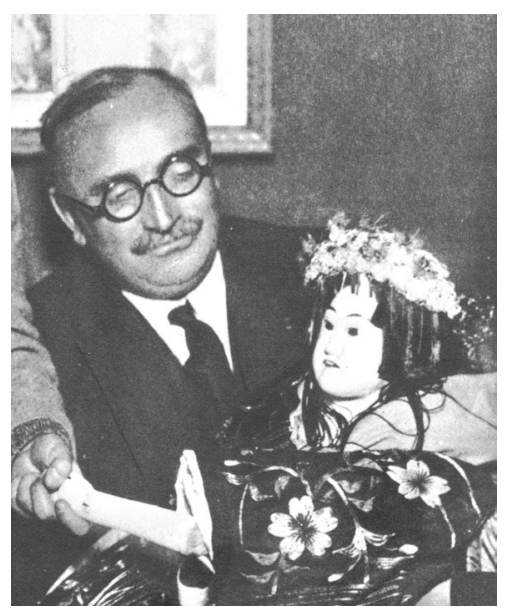

As relações com L’homme et son désir são nítidas, apenas reforçadas pelas diferenças que reposicionam culturalmente o enredo. O personagem masculino, agora não mais o protagonista, abandona

\section{Vera Beatriz Siqueira}

A floresta geométrica de Paul

Claudel: fronteira entre dois mundos.

35. CLAUDEL, 2011, p. 1466.
Fig. 16

Paul Claudel com uma marionete bunraku de Osaka, Japão, 1926. (foto sem autoria) Fonte: <https://goo.gl/ byDmQf>. 
ARS sua natureza original ambígua (entre o homem que dorme e o que

ano 15

n. 31

36. Claudel retira essa imagem de "limite entre dois mundos" de um conto chinês, também lido na obra do padre jesuíta Wieger de 1909, recolhendo o chamado Folclore chinês moderno. Trata-se de uma lenda sobre um ministro da dinastia Han que, estando um dia em uma montanha, no meio de um nevoeiro, se vê diante de uma estela em ruína, na qual consegue apenas decifrar a inscrição: "Limite des deux mondes". CLAUDEL, 1965, p. 184. A peça La femme et son ombre será publicada com o subtítulo Fronteira entre dois mundos. aparece em seu sonho) e transforma-se em guerreiro. A ambivalência transfere-se para a mulher que possui dupla realidade: é a mulher viva e também sua sombra, o fantasma da amada morta. Tudo se passa em uma área deserta e nebulosa que representa a "fronteira entre dois mundos" ${ }^{\text {, }}$, outro modo abstrato de figurar o espaço ambivalente da floresta profunda e sua conexão com o mundo interior. $\mathrm{O}$ palco é igualmente dividido em níveis, sendo que agora são três patamares: o superior ocupado pela Lua, o inferior por seu reflexo e o do meio pelos atores. Novamente, o tema central é o encontro do homem com o fantasma de quem amou. No balé criado no Brasil para europeus, o homem é distraído pelos seres da floresta. Neste, escrito por um europeu para japoneses, cabe à mulher viva implicar com ele, distraí-lo com cantos ou mesmo encobrir com seu próprio corpo o espectro de seu duplo. Enquanto no primeiro balé a procissão das Horas era consoladora, relativizando o drama humano, na peça japonesa, na qual o passar das horas está ausente, o trágico se impõe. O Homem tenta, em vão, separar a Mulher de sua sombra, mas acaba por matá-la. As roupas pesadas da Mulher e seus gestos hipnóticos na luta contra a sombra ajudam a tornar seus movimentos a expressão vívida dessa paixão mortal.

O balé de Claudel dialoga livremente com o teatro tradicional japonês, novamente aproximando-se de uma imagem caricata de si mesmo, o que, de certo modo, não estava ausente do próprio kabuki, marcado pelo exagero de gestos, figurino e maquiagem. A coreografia vale-se especialmente das convenções de movimentos lentos, rígidos e sutis que, combinados à música, ganham sentido de transe. A música "puramente japonesa" de sua peça - executada por instrumentos como shamisen (espécie de banjo de três cordas), flauta, pequeno violino, harpa de madeira, gongo, tambores, além dos cantores - articula-se a essa imagem convencional. A reação crítica no Japão varia entre a severidade e a condescendência, mesmo levando-se em conta a recepção calorosa e entusiasmada que Claudel teve em Tóquio, onde muitos intelectuais viam-no como representante de uma posição contrária ao imperialismo, ao militarismo e ao utilitarismo que reinavam à época. As críticas dirigem-se mais ao dispositivo cênico do que ao texto, talvez justamente por estranharem essa formulação deliberadamente estereotipada, na qual a tradição japonesa se converte em algo entre a bufonaria e a nostalgia (Fig. 17). 


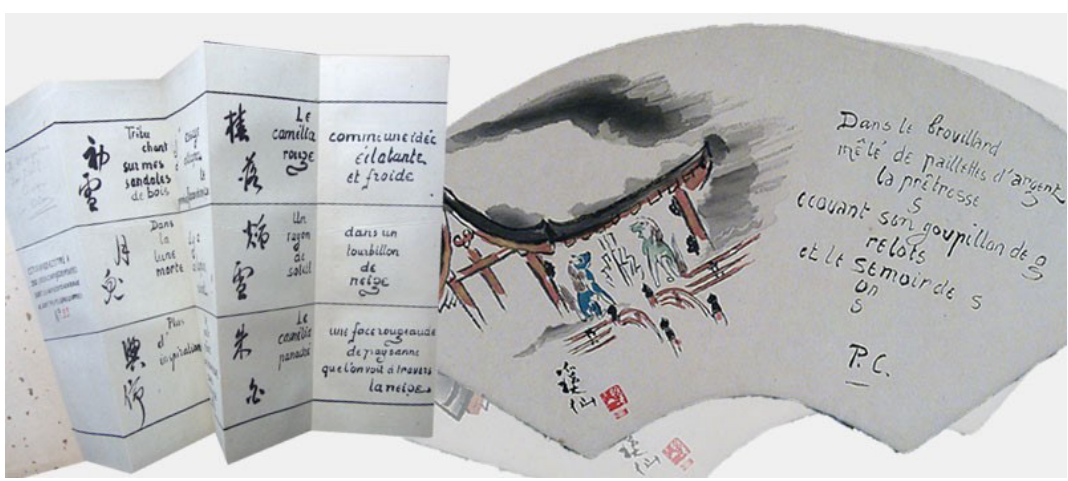

É curioso notar, nessa readaptação do tema imaginado no Brasil, os trânsitos culturais que o formam. Quando chega ao Rio de Janeiro do início do século XX, Claudel encontra uma cidade orgulhosa de sua modernização, após passar pela reforma urbana mais radical de sua história, empreendida pelo prefeito Pereira Passos. Encontra também os rastros de uma história colonial e escravocrata, a qual tende a ver com olhos menos críticos, seja pelo elogio à jovialidade da elite, derivada do fato de não ter sido pressionada pela lógica do trabalho, seja pelo encanto com a religiosidade afrodescendente em seu diálogo com o catolicismo. Em terras cariocas, elogia a procissão da Sexta-feira Santa:

A cruz, duas linhas de velas. As pequenas meninas vestidas como anjos que carregam todos os acessórios da Paixão, incluindo o galo e o crânio. $\mathrm{O}$ bumbo atrás batendo suavemente em pancadas surdas. Toda essa loucura cheia de negros andando atrás do clarão das palmeiras, iluminadas pela lua brilhante. ${ }^{37}$

Em Salvador, admira a "massa pitoresca de mulheres negras" nos arredores da igreja de Nosso Senhor do Bonfim:

Poderosas negras da Bahia em suas melhores roupas. Amplas saias engomadas, camisola ou camisa de renda de onde emergem seus corpos cor de chocolate, turbantes, colares de grãos ou de placas douradas, e seus braços marrons, os pulsos rodeados por um amplo bracelete com sinos dourados, a mão recolhida segurando uma fruta bizarra e bem verde. ${ }^{38}$

No Japão da década de 1920, depara-se com um país orgulhoso que, após haver participado da guerra ao lado dos Aliados, encontra-se em franco desenvolvimento econômico, aberto às influências culturais
80

Vera Beatriz Siqueira

A floresta geométrica de Paul

Claudel: fronteira entre dois

mundos.

Fig. 17

Paul Claudel, Cent Phrases pour éventails, publicação de 1941 que apresenta os poemas inspirados na tradição haikai, escritos entre 1926 e 1931, em parceria com o pintor japonês Tomita Keisen (1877-1936) e publicados originalmente em Shi-fu-jô (Souffle des quatre souffles), com quatro poemas aquarelados em forma de leques. (foto sem autoria). Fonte: <https://goo.gl/T5Yvka>.

37. CLAUDEL apud FLEURY, Op. cit., p. 241.

38. Ibidem, p. 242. 
ocidentais, mas imerso no militarismo e nos ideais imperialistas. Se, no Brasil, Claudel era Cacique, no Japão adotou o pseudônimo Kuro Tori (Pássaro Negro), interessando-se particularmente pelo que chamou de "alma japonesa”, perscrutada na peculiar relação dos japoneses com a natureza que, segundo o poeta, "é um templo já pronto e disposto para o culto", formado por

sítios silenciosos e solenes aos quais conduzem longos desvios parecidos com os de uma iniciação, sombras funerárias, objetos singulares como um velho tronco de árvore, uma pedra gasta pela água, semelhantes a documentos indecifráveis e sagrados, perspectivas descobertas apenas através do pórtico de rochas, da colunata de árvores. ${ }^{39}$

Nessas descrições manifesta-se o olhar refinado do poeta simbolista e católico, e seu correlato desejo de dotar a natureza de espiritualidade. Mas é importante notar que seu diálogo com as culturas brasileiras e japonesas também se deixou impregnar pelo clima intelectual local que, em ambos os casos e guardadas as devidas diferenças, buscava atualizar as heranças e tradições, tornando-as parte da modernização do país. Mais relevante, no entanto, é o fato de, ao descrever a natureza e a cultura de Brasil e Japão, Claudel ter recorrido a imagens poéticas que falam da força da estranheza, da sua indecifrabilidade, da possibilidade de descrição apenas por meio de outras imagens aproximativas. Nos trajetos físicos e simbólicos de L’homme et son désir, entre Pequim, Praga, Paris, Rio e Tóquio, Claudel compreende que há algo impossível de se transportar e traduzir.

Questão que já aparece logo após retornar do Brasil, quando se dedica a produzir, a partir da Dinamarca, onde se encontrava na época, a montagem do primeiro espetáculo. Em determinado momento, em suas conversas com Parr e Milhaud, imagina que o melhor seria mudar o nome do balé para L'homme et la fôret, o que acaba não acontecendo. Essa ideia visava destacar a centralidade da própria floresta tropical na escritura da trama, mas continha uma autocrítica. Afinal, uma coisa era falar de espíritos no lugar em que a floresta é um fato concreto, concedendo interioridade à exuberância da natureza tropical. Falar de espíritos em Paris, por outro lado, parecia-lhe quase ridículo, possivelmente redundante e algo reacionário no quadro da modernidade artística. Quando, mais tarde, se recusa a encenar L'homme et son désir no Japão, o faz por entender exatamente a incomunicabilidade essencial dos diálogos culturais, nos quais as mesmas palavras 
carregam sentidos tão diversos, donde a necessidade de ambientação do tema e de sua forma à cena cultural japonesa.

Trata-se, portanto, da consciência do problema que vem sendo tratado hoje, dentro dos estudos da antropologia e da história da arte, como a incomensurabilidade das culturas. Mas, ao contrário de alguns dos estudiosos contemporâneos, que se valem da premissa de que as culturas divergem em seus pressupostos (ou pontos de vista) sobre espaço, tempo e história, concluindo, portanto, que seria inútil tentar relacioná-las ou compará-las, Claudel assume uma perspectiva menos amarga e mais poética. Criado no aprisco doméstico e intelectual de seu exílio no Brasil durante a guerra, L'homme et son désir fala das tentativas desse grupo de artistas franceses não apenas de conhecer, mas também de pertencer a um lugar estranho, indescritível ou inabordável ${ }^{40}$.

Em vez de rejeitar ou condenar a estranheza, lugar-comum nas relações de viajantes com o Brasil, Claudel, Milhaud e Parr preferem incorporá-la como força, não para decifrá-la, e sim para anexar o seu mistério, a ponto de desafiar os próprios fundamentos da criação artística. É claro que essa incorporação não estava (e jamais estaria) isenta dos preconceitos e limites que tradicionalmente fundam os diálogos interculturais. Mais ainda, estava intimamente associada à preocupação de Claudel, esse escritor viajante, de repensar e reposicionar as tradições europeias, clássica e cristã, com seus pressupostos de eternidade em crise, no quadro do mundo moderno. Sua escrita não é propriamente universal, e sim cosmopolita. Quando o escritor e amigo de Claudel, Francis Jammes, procura resumir o que chama de "colmeia" da obra de Claudel, assim escreve:

Os espíritos que colaboraram para a excelência de seu mel são os profetas, os santos, os trágicos e filósofos gregos, Virgílio, Shakespeare, Pascal, os macacos de luvas brancas que colhem um chá virgem às bordas do rio Azul, os professores de violoncelo de Praga, os engenheiros da Transiberiana, os camelôs de Pequim (...), os chefes de estação alemães, a negra do Brasil que colecionava borboleta, os especialistas em terremotos do Japão, os tripeiros de Chicago, os conselheiros gerais de Aisne e Ain, os diplomatas, as paisagens de Champagne, os acadêmicos. ${ }^{41}$

Ao elencar tal panteão de influências, configurando o cosmopolitismo intertextual de Claudel, Jammes faz questão de qualificar o contato do amigo com o outro, com o exótico, como um

\section{Vera Beatriz Siqueira}

A floresta geométrica de Paul

Claudel: fronteira entre dois mundos.

40. Sobre isso, cf. CAVELL, Stanley. Essa América nova, ainda inabordável: palestras a partir de Emerson e Wittgenstein. São Paulo: Editora 34, 1997.

41. DETHURENS, Pascal.

"L'Europe écrit..." ou Spirales et labyrinthes du texte européen. In: Claudel et l'avènement de la modernité. Paris: Presses Universitaires de Franche-Comté, 1996, p. 382. 
interesse humano pelo ordinário e pelo particular. Do Brasil, não são citados artistas, intelectuais e trabalhadores, como de outros locais. Comparece essa figura quase fabulosa, a negra que colecionava borboletas, sintetizando poeticamente sua visão sobre o país: um mistério indecifrável, que reúne a figura arquetípica da mulher negra, cuja presença nos fala imediatamente de violência e submissão, mas também de resistência e potência cultural, com a tarefa delicada e improdutiva de recolher borboletas em seu voo e fixá-las em sua finada beleza. Trata-se de "a" negra, portanto, típica e universal. Mas "do Brasil", logo, localizada e particular. Seu interesse advém da ação transgressora que realiza - colecionar borboletas -, um ato frequentemente restrito a botânicos ou diletantes, em nítida oposição ao trabalho imediatamente associado às negras outrora escravizadas, como lavar roupa, fazer faxina, cozinhar. Fala, assim, de um universo cultural complexo, de uma sociabilidade porosa.

Podemos visualizar uma negra poderosa e bela, como as que Claudel vira nas ruas de Salvador ou como as que seu conterrâneo Jean-Baptiste Debret (1768-1848) retratara um século antes, igualmente na situação ambígua de escravas de ganho (Fig. 18). Podemos imaginá-la frequentando, como as borboletas que coleciona, as bordas da floresta tropical de Claudel, conferindo poesia e profundidade ao gesto simples, infecundo e suavemente perverso que executa. Podemos vê-la a caçar as onipresentes borboletas amarelas da Mata Atlântica, com seus impressionantes desenhos em preto, mimetizando olhos de animais assustadores, ou as incríveis borboletas azuis do gênero Morpho (epíteto da deusa Afrodite), que povoam as florestas tropicais do continente americano, e cuja cor é, em realidade, parda ou ocre, mas obtém a coloração metálica azul-turquesa ou cobalto pela reação química produzida pela entrada da luz nos alvéolos de suas escamas. Podemos ainda supor que a "negra do Brasil" embala a cuidadosa fixação em pranchas desses seres belos e impressionantes, entoando um dos sambas, maxixes ou tangos - tão admirados por Milhaud - "cuja

42. MILHAUD apud THOMPSON, Op. cit. grandeza vem da mesmice" ${ }^{42}$, da repetição da singeleza até convertê-la em imponência. Podemos, por fim, entender essa figura poética - a negra colecionadora de borboletas - como parte das pungentes imagens de Brasil de Paul Claudel, mais uma de suas figuras indecifráveis, entre a caricatura e a reminiscência, formada de "materiais excêntricos e inutilizáveis", prenhes de "pequenos nadas" significativos. 


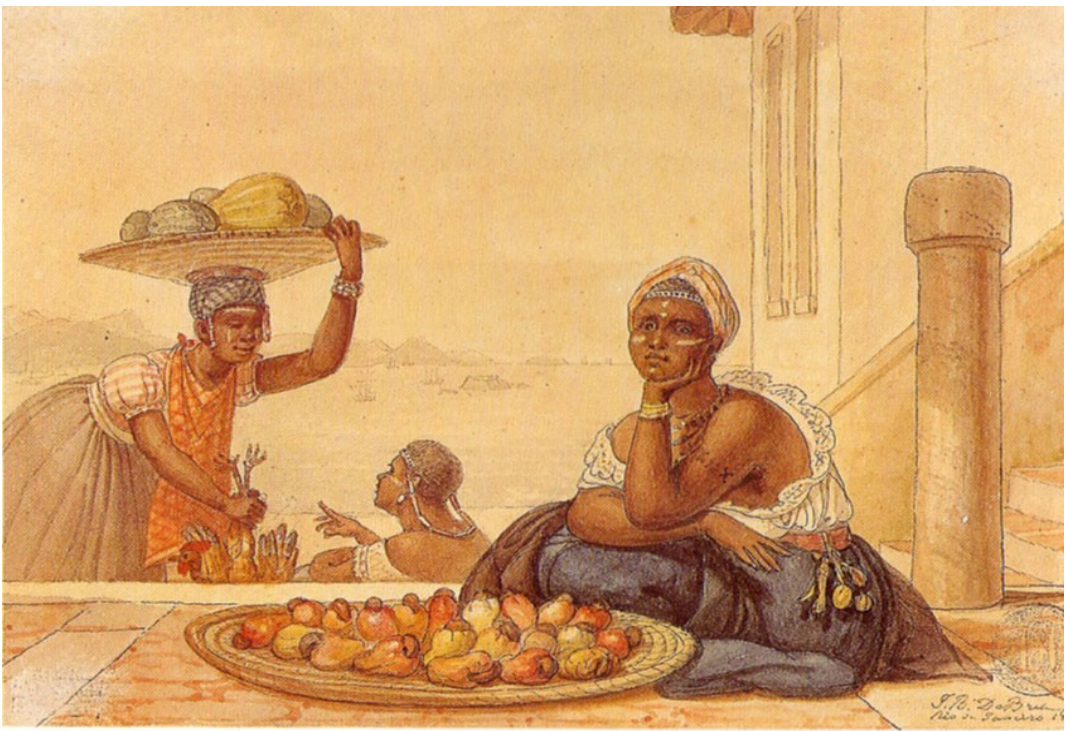

\section{Bibliografia complementar}

NISHINO, Ayako. La réception japonaise des Nô claudéliens: La Femme et son Ombre, de 1923 a 2005. In: ALEXANDRE-BERGUES, Pascale; ALEXANDRE, Didier; LÉCROART, Pascal (orgs.). Paul Claudel et l'histoire littéraire: actes du colloque. Paris: Presses Universitaires de Franche-Comté, 2010.
84

Vera Beatriz Siqueira

A floresta geométrica de Paul

Claudel: fronteira entre dois

mundos.

Fig. 18

Jean-Baptiste Debret, Negra tatuada vendedora de caju, 1827, aquarela sobre papel, Acervo Museus Castro Maya/ Ibram/MinC, Rio de Janeiro. Fonte: <https://goo.gl/ HHxncw $>$. 